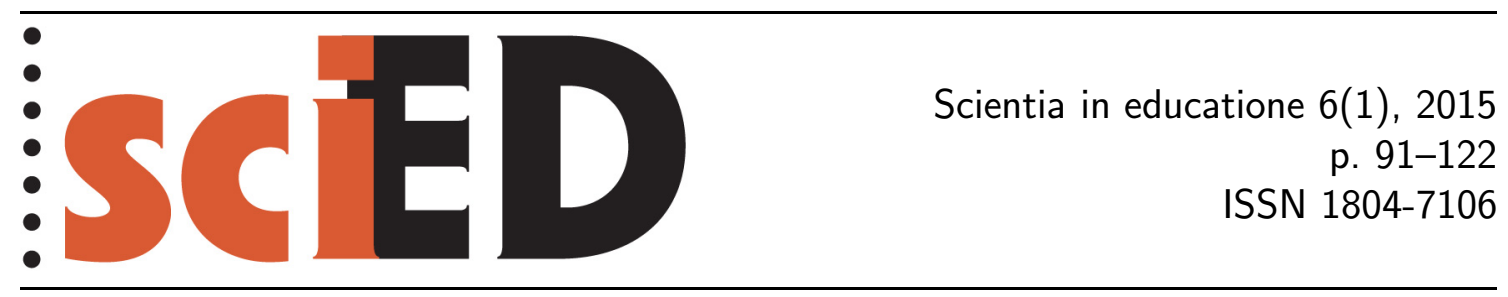

\title{
Badatelsky orientované vyučování matematice
}

\author{
Libuše Samková, Alena Hošpesová, Filip Roubiček, Marie Tichá
}

\begin{abstract}
Abstrakt
Tento text je shrnutím našich dosavadních poznatků o uplatňování myšlenek badatelsky orientovaného vyučování matematice. Po nezbytném vymezení některých pojmů v něm představujeme, jak je chápáno badatelsky orientované vyučování matematice. Využíváme podněty přicházející z didaktiky přírodovědných předmětů a navazujeme na související podněty a poznatky z didaktiky matematiky. Ukazujeme, (a) jak existující didaktické teorie a podoby školní praxe v matematickém vzdělávání korespondují s badatelsky orientovaným vyučováním; (b) co může být zdrojem matematického bádání ve škole; (c) čím jsou charakteristické matematické úlohy, které mohou vést $\mathrm{k}$ badatelským aktivitám žáků. V závěru uvádíme náměty několika úloh podněcujících badatelsky orientované vyučování matematice.
\end{abstract}

Klíčová slova: badatelsky orientované vyučování matematice, bádání, vědecké bádání, badatelská úloha, badatelské aktivity žáků.

\section{Inquiry-based Mathematics Teaching}

\begin{abstract}
The study summarizes current knowledge of the implementation of inquiry-based mathematics teaching. After the necessary explanation of several concepts we introduce our understanding of inquiry-based teaching in mathematics. Our thoughts are inspired by stimuli from science education, and based on related stimuli and findings in mathematics education. We show (a) how existing educational theories and forms of school practice correspond to the inquiry-based mathematics teaching; (b) what can be a source of mathematical inquiry in school; (c) what are the characteristic mathematical tasks that may lead to inquiry activities of pupils. At the end, we propose several tasks suitable for stimulating inquiry-based mathematics teaching.
\end{abstract}

Key words: inquiry-based mathematics teaching, inquiry, scientific inquiry, inquiry-stimulating task, inquiry activities of pupils. 
Inquiry-based mathematics education refers to a student-centered paradigm of teaching mathematics and science, in which students are invited to work in ways similar to how mathematicians and scientists work.

Encyclopedia of Mathematics Education (Dorier \& Maaß, 2014: s. 300)

Badatelsky orientované vyučování (BOV) je v poslední době často diskutovanou možností, jak obohatit vzdělávání v přírodovědných předmětech a matematice. Předpokládá se, že zvýší zájem žáků o př́rodovědné předměty a zkvalitní jejich učení. Myšlenky, na kterých je BOV vystavěno, lze vysledovat v odborné literatuře. V procesu jejich současného uplatňování jsou však často zjednodušovány, aby byly snadno sdělitelné, a jejich návaznost na dosavadní výsledky tak nebývá čitelná.

Tento text je míněn jako souhrn našich dosavadních zjištění o původu a zdrojích myšlenek badatelsky orientovaného vyučování matematice (BOVM) u nás i ve světě, který směřuje $\mathrm{k}$ odpovědím na následující otázky:

Jak je chápáno BOVM a jaké podněty pro matematiku přineslo uplatňování BOV v přírodovědných předmětech?

Jak existující didaktické teorie a podoby školní praxe v matematickém vzdělávání korespondují s BOVM?

Jak lze vytvořit vhodné prostředí pro BOVM, neboli čím jsou charakteristické matematické úlohy, které mohou vést $\mathrm{k}$ badatelským aktivitám žáků?

V závěrečné části textu uvádíme náměty 20 matematických úloh podněcujících bádání.

Východiskem našich úvah se stala přehledová studie (Artigue \& Blomhøj, 2013).

\section{1 ÚVODNÍ POZNÁMKY K TERMINOLOGII}

Vztah českého vzdělávacího prostředí a BOVM je negativně zatížen některými nejasnostmi v terminologii. Tyto nejasnosti jsou ponejvíce způsobeny souhrou následujících faktorů: (i) většina volně dostupných (zpravidla internetových) materiálů o BOV je v angličtině; (ii) česká terminologie související s BOV není zcela v souladu s anglickou; (iii) terminologie související s BOVM neodpovídá zcela terminologii BOV v ostatních předmětech. Navíc prostřednictvím BOVM nepřímo vstupuje do vyučovacího procesu matematika na odborné (vědecké) úrovni, a tak dalším neopominutelným faktorem jsou př́ípadné nesrovnalosti v terminologii odborně matematické a didaktické. Považujeme tedy za velmi důležité hned v úvodu našeho příspěvku vymezit používané pojmy tak, aby se čtenář správně orientoval nejen v českém, ale případně i v anglickém prostředí BOV, a mohl mezi těmito prostředími plynule přecházet.

Termín badatelsky orientované vyučování je překladem termínu inquiry-based teaching. Klíčovou aktivitou badatelsky orientovaného vyučování je inquiry, což je v tomto kontextu překládáno jako bádání.

$\mathrm{V}$ anglických textech o BOV se velice často vyskytuje slovo science, a to jako substantivum nebo adjektivum. Substantivum science má v angličtině 3 různé významy, všechny související s BOV: (i) věda jako disciplína; (ii) věda jako odborná znalost; (iii) ve školním prostředí je science označením pro skupinu předmětů zahrnující biologii, fyziku a chemii, a to na všech stupních škol, včetně propedeutik. Za nejvhodnější překlad významu (iii) považujeme termín př́rodovědné předměty (srov. Mareš \& Gavora, 1999: s. 152). 
Se substantivem science souvisejí dvě adjektiva: adjektivum scientific patří k významům (i), (ii) a překládá se jako vědecký, adjektivum science patř́ k významu (iii) a př̀kládá se jako přírodovědný. Termín scientific inquiry tak odkazuje na bádání $\mathrm{z}$ pohledu vědy, přeložit ho můžeme jako vědecké bádání. Termín science inquiry odkazuje na bádání v rámci př́rodovědných předmětů, překládáme ho jako př́rodovědné bádání. Slovo science se v textech může objevovat vícekrát za sebou v různých významech, jako například $\mathrm{v}$ hesle nature of science in science education, které se přeloží jako povaha vědy v př́rodovědném vzdělávání.

Další terminologické nesrovnalosti souvisejí s anglickými termíny problem a problem solving. $\mathrm{V}$ anglicky psané literatuře se zpravidla užívá termín problem, někdy task, ale $\mathrm{v}$ učebnicích se lze setkat i s (routine) exercise. U nás se zpravidla uživá termín úloha (v poslední době problém) a velmi často (zvláště ve školské praxi) př́klad.

Na tomto místě připomeňme myšlenku J. Vyšína, který k označením problém, úloha, cvičeni a př́klad podal tento výklad:

Slovo „cvičení“ má v naší didaktice jasný význam: je to úloha, která slouží obvykle k procvičování probraných stereotypů, algoritmů, početních i grafických postupů, vzorců apod. Mezi názvy „úloha“ a „problém“ se zpravidla nedělá valný rozdíl. Úlohou budeme rozumět zadání situace dosud typově neřešené, kde vystačíme v podstatě s poznatky a aparátem známým. U problému budeme vždy předpokládat větší podíl řešitelovy tvořivosti a vynalézavosti. Je zřejmé, že přesnou hranici nelze vést, že však také úloha, která je pro řešitele s nižší matematickou úrovní problémem, je pro školenějšího řešitele prostě cvičením.

Ještě několik slov o názvu „př́ḱklad“. Budeme jím rozumět zpravidla „vzorový prŕklad“, tj. text úlohy doplněný jedním nebo více řešeními. (Vyšín, 1962: s. 7)

Úlohy a problémy poskytují půdu pro badatelsky orientované vyučování. Podle Kuřiny (2011) matematickou úlohou rozumíme jakoukoli výzvu k matematické činnosti zaměřené na dosažení určitého cíle; mluvíme o řešení úlohy.

Ještě je tu otázka, jak rozumět slovu úkol. To se vyskytuje často ve smyslu pokynu k vytvoření, vypracování něčeho, např́klad v souvislosti s pokynem „vytvořit úlohu“ jsme mluvili o zadání úkolu.

Různé teoretické rámce vymezují rozdílně také pojem otevřená úloha, v tomto př́spěvku jej budeme užívat ve smyslu tzv. otevřeného přístupu k výuce matematiky (open approach; Nohda, 2000; Pehkonen, 1995). V tomto pojetí se otevřenou úlohou rozumí každá úloha, jejíž výchozí nebo cílová situace je otevřená, tj. není přesně určená (přesně vysvětlená). ${ }^{1}$ Tyto úlohy jsou podle Nohdy (2000) trojího typu: úlohy s otevřeným postupem řešení (existuje více správných způsobů, jak úlohu vyřešit), úlohy s otevřeným koncem (existuje více správných odpovědí) a úlohy, u kterých existuje více možností, jak úlohu dále rozvíjet. Jednotlivé typy otevřených úloh se prolínají, jedna a tatáž úloha může náležet $\mathrm{k}$ více typům zároveň.

Poslední terminologická poznámka se týká vymezení pojmů model a matematický model. Termín model má široký význam, obecně se jedná o „systém prvků, operací,

\footnotetext{
${ }^{1}$ Tento př́stup se odlišuje od chápání pojmu otevřená úloha ve smyslu „problém s tvorbou odpovědí" (Zhouf, 2010: s. 28) jako protikladu k pojmu uzavřená úloha.
} 
vztahů a pravidel, které je možné použít k popisu, vysvětlení nebo předvídání nějakého jiného známého systému" (Doerr \& English, 2003: s. 112; srov. Kuřina, 1978: s. $\left.642-643^{2}\right)$. Modelováním se rozumí proces tvorby a užití modelu.

V matematickém vzdělávání má modelování mnoho podob, např. Kaiserová a Sriraman (2006) rozlišují aktuálně 7 různých přístupů k modelování - realistický, kontextuální, didaktický, konceptuální, sociálně-kritický, epistemologický a kognitivní. ${ }^{3}$ V českém vzdělávacím prostředí se nejčastěji setkáme s pojmem model v kontextu poznávacího procesu (např. Hejný \& Kư̌ina, 2009: s. 128). Ve výše uvedené klasifikaci se jedná o kombinaci didaktického a konceptuálního př́istupu:

V poznávacím procesu člověk obvykle porozumí několika konkrétním příkladům, všímá si, co mají společného, a dochází tak k obecnějším a abstraktnějším poznatkům. Jádrem poznávacího procesu jsou dva mentální zdvihy: první vede od izolovaných modelů k univerzálním a druhý od univerzálních modelů k abstraktní znalosti. Model chápeme jako metodologický prostředek k tomu, abychom se „vyznali v situaci“. Soustředíme-li své úsilí při studiu problému na určitou jeho stránku, organizujeme své zkušenosti přirozeně tak, abychom ji co nejlépe poznali, vytváříme oddělené pohledy na problém, které vedou $\mathrm{k}$ izolovaným modelům studovaných jevů. Univerzální model má obecnější charakter než libovolný izolovaný model. Izolovaný model má charakter ukázky, univerzální model představuje obecný návod, algoritmus, vzorec, graf. Univerzální model je takový popis situace ve vhodném jazyku, který umožňuje předpovídání. (Hejný \& Kư̌ina, 2009: s. 128, 131-132)

Termín matematický model se ve vyučování matematice v českém prostředí vztahuje zpravidla k aplikačnímu kontextu; je prostředkem pro odhalování matematických struktur v jevech, které obecně nejsou matematické, vycházejí např. z fyziky, techniky, biologie, sociologie, ekonomie apod. (podrobněji v 4.4).

Základní koncept modelu a matematického modelu je tedy stejný, oba jsou prostředkem pro odhalování matematických struktur. Liší se však polem působnosti: zatímco ve vyučování jsou modely používány za účelem ujasnění, uchopení matematické struktury/matematického pojmu (představa o pojmu se utváří na základě jeho různých reprezentací), matematický model zprostředkovává odhalení matematických struktur v realitě mimo matematické prostředí.

\footnotetext{
${ }^{2}$ „Vědecké poznání lze charakterizovat jako proces, jehož prostřednictvím získává člověk znalosti o objektivní realitě. Jestliže se podaří popsat část skutečnosti v jistém jazyku natolik výstižně, že lze jen z tohoto popisu zjištovat některé poznatky, které nebyly bezprostředně patrné při zkoumání reality, má takovýto popis význam pro růst našeho poznání a budeme ho nazývat modelem uvažované části skutečnosti. Model je tedy takový popis objektivní reality v jistém jazyku, který umožňuje předpovídání."

${ }^{3}$ Hlavní cíle jednotlivých přístupů: realistický přístup - čistě praktické cíle; kontextuální - cíle obsahové a psychologické; didaktický - cíle pedagogické a obsahové, zaměřen na strukturu procesů učení; konceptuální - cíle pedagogické a obsahové, zaměřen na představování konceptů a jejich rozvoj; sociálně-kritický - cíle pedagogické, např. kritické chápání okolního světa; epistemologický cíle teoretické, zaměřen na teoretické rámce a jejich rozvoj; kognitivní - cíle výzkumné a psychologické, např. analýza kognitivních procesů probíhajících během modelování (metapřístup). (Kaiser \& Sriraman, 2006: s. 304)
} 


\section{IMPLEMENTACE BOV VE VZDĚLÁVÁNí}

Ve větší míře se s termínem BOV v ČR setkáváme až v posledních pěti letech; ještě v roce 2010 konstatoval Papáček, že:

I když např. Janoušková, Novák a Maršák (2008) se tímto vzdělávacím směrem ve svém článku zabývají, didaktika př́rodopisu, resp. biologie a geologie v Čechách termíny ,inquiry“ nebo „badatelsky orientované vyučování“ zatím plošněji neužívá. (Papáček, 2010: s. 41)

Do českého vzdělávacího prostředí pronikl termín BOV hlavně prostřednictvím mezinárodních projekti̊ zaměřených na badatelsky orientované vzdělávání financovaných ze Sedmého rámcového evropského výzkumného programu. Zaměření projektů reflektovalo celosvětový trend; nejprve se objevily BOV projekty pro prŕrodovědné předměty $(\mathrm{P})$ a teprve poté projekty kombinující přírodovědné předměty a matematiku $(\mathrm{P}+\mathrm{M})$ :

S-TEAM (2009-2011), s-teamproject.eu, P, český partner: PF JU;

ESTABLISH (2010-2014), www.establish-fp7.eu, P, český partner: MFF UK;

PROFILES (2011-2014), www.profiles-project.eu, P, český partner: PedF MU;

PRI-SCI-NET (2011-2014), www.prisci.net, P, český partner: PF UJEP;

FIBONACCI (2010-2013, v ČR od září 2011), www.fibonacci-project.eu, $\mathrm{P}+\mathrm{M}$, český partner: PF JU;

ASSIST-ME (2013-2016), assistme.ku.dk, P + M, český partner: PF JU;

MaSciL (2013-2016), www.mascil-project.eu, P + M, český partner: PřF UHK.

Tyto projekty hlavně reagovaly na publikaci National Science Education Standards (NRC, 1996), která př́ímo vyzývala k takové výchově žáků a studentů, aby věděli, co je to vědecké bádání, a aby sami vědecké bádání prováděli. Tato publikace rozlišuje vědecké bádání a bádání:

Vědecké bádáni se vztahuje k různým zpo̊sobům, kterými vědci studují svět a nabízejí vysvětlení založená na důkazech získaných při jejich práci.

Bádání zahrnuje činnosti žáků, při kterých rozvíjejí své znalosti a porozumění vědeckým myšlenkám:

- pozorování;

- kladení otázek;

- vyhledávání informací v knihách a dalších zdrojích (aby zjistili, co je již známo);

- plánování výzkumu, navrhování postupů zkoumání;

- přezkoumávání toho, co je již známo, na základě experimentálních výsledků;

- využívání nástrojů pro sběr, analýzu a interpretaci dat;

- formulování odpovědí, vysvětlení a předpovědí;

- sdělování závěrů. 
Bádání vyžaduje identifikaci předpokladů, využití kritického a logického myšlení, zvažování alternativních vysvětlení. (NRC, 1996: s. $23^{4}$, vlastní preklad)

Za základ badatelsky orientovaného vyučování je považováno pochopení povahy vědy. Podle Ledermana et al. (2002) a Schwartzové, Ledermana a Crawfordové (2004) patří k pochopení povahy vědy uvědomení si skutečnosti, že vědecké poznatky jsou:

- provizorní (kdykoliv je mohou změnit nová pozorování nebo nové interpretace předchozích pozorování);

- empirické (založené na zkušenostech a pozorováních, přičemž tato pozorování jsou často zprostředkována přístroji a jejich funkčností také limitována);

- kreativní (jsou vytvořeny kombinací lidské představivosti a logického uvažování);

- subjektivní (formování vědeckých poznatků je ovlivňováno a řízeno aktuálně akceptovanými vědeckými teoriemi a zákony - na nich záleží výběr otázek, směr výzkumu a způsob interpretace dat; je také ovlivňováno osobou vědce, jeho pracovními návyky, předchozími zkušenostmi);

- sociokulturní (způsob provedení výzkumu, interpretace, přijetí a využití jeho výsledků závisí na společnosti a kultuře, ve kterých je výzkum prováděn);

a že ve vědě neexistuje žádný univerzální postup - vědecká metoda, která by spolehlivě vedla k získání nových vědeckých poznatků.

Schwartzová, Lederman a Crawfordová dále uvádějí, že vědecké poznatky mohou být ve formě:

- zákonů (popisu vztahů mezi přírodními jevy);

- teorií (vysvětlení př́rodních jevů, vztahů mezi nimi a jejich mechanizmů);

- hypotéz (pokud je potvrdí další výzkum, mohou z nich vzniknout zákony nebo teorie);

a že je nutné tyto formy důsledně rozlišovat.

Bádání jako imitace vědeckého bádání může mít bud’ praktický, nebo teoretický základ, nebot některé vědecké výzkumy jsou určeny praktickým problémem, který je třeba vyřešit, zatímco jiné jsou určeny intuicí nebo zajímavými teoretickými souvislostmi (tj. cestou, která je vidět). Zvláště v oblasti odborné matematiky nalezneme mnoho vědeckých výzkumů, které jsou čistě teoretické. $K$ praktickému využití jejich výsledků dochází s časovým odstupem, někdy i o mnoho let či desetiletí později. Jak poukazuje Arnold (2000: s. 403), tak zkušenosti z minulých století ukazují, že matematika se nerozvíjí díky technickému pokroku (přestože snahám o přispění k technickému pokroku, tedy k praktickému využití, je věnována většina času a úsilí matematiků), ale spíše díky objevům neočekávaných vztahů mezi různými oblastmi

\footnotetext{
${ }^{4} \mathrm{~V}$ původním znění: „Scientific inquiry refers to the diverse ways in which scientists study the natural world and propose explanations based on the evidence derived from their work. Inquiry also refers to the activities of students in which they develop knowledge and understanding of scientific ideas, as well as an understanding of how scientists study the natural world. Inquiry is a multifaceted activity that involves making observations; posing questions; examining books and other sources of information to see what is already known; planning investigations; reviewing what is already known in light of experimental evidence; using tools to gather, analyze, and interpret data; proposing answers, explanations, and predictions; and communicating the results. Inquiry requires identification of assumptions, use of critical and logical thinking, and consideration of alternative explanations."
} 
matematiky (které však byly objeveny právě díky neúspěšným snahám o technický pokrok).

Implementaci aspektů souvisejících s povahou vědy do přírodovědného vzdělávání se rozsáhleji věnuje kniha (McComas, 1998). Pochopení povahy vědy pomáhá výuka orientovaná na:

- pozorování a jeho různé interpretace;

- řešení problémů, jejichž vstupní informace mohou být nekompletní a mají nejasnou důležitost;

- řešení problémů, které mají nejasný počet nejasně klasifikovatelných řešení (nedá se jednoznačně určit, které řešení je správné, nejlepší apod.).

Schematicky lze BOV znázornit jako průnik čtyř charakteristik: záměrů kurikula, žákovských a učitelových aktivit specifických pro takto zaměřenou výuku a kultury vyučování (viz obr. 1).

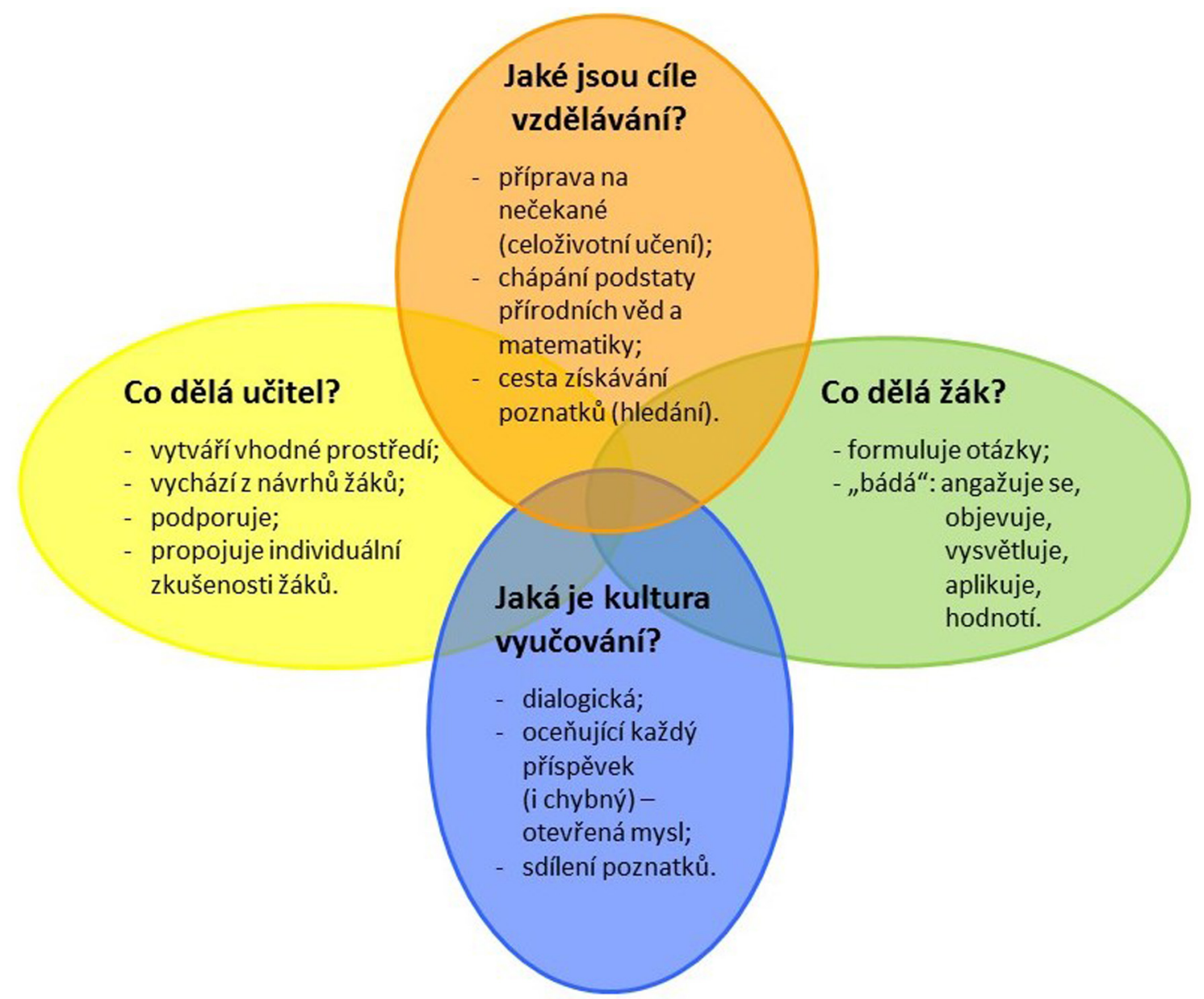

Obr. 1: Charakteristiky badatelsky orientované výuky; inspirováno (Dorier \& Maaß, 2014: s. 302)

Není překvapivé, že role žáka a učitele se v tomto pojetí výuky oproti transmisivnímu přístupu ${ }^{5}$ výrazně mění. Požadujeme-li, aby žák pozoroval, hledal aktivně

\footnotetext{
${ }^{5}$ Transmisivní vyučování: „Ve stručnosti jde o vyučování zaměřené na výkon žáka spíše než na rozvoj jeho osobnosti. Učitel se v transmisivně vedené výuce snaží předat žákům a studentům již hotové znalosti v dobré viřre, že toto je nejlehčí a nejrychlejší cesta $\mathrm{k}$ poznání. Žák je viděn v roli pasivního př́jemce a ukladatele vědomostí do paměti, aniž by se kladl důraz na jejich vzájemné propojení." (Stehlíková, 2004: s. 19)
} 
informace, dedukoval, vytvářel a diskutoval o hypotézách, ověřoval je apod., učitel musí pro tyto činnosti vytvořit vhodné prostředí. Jeho úkolem je spíše vytvářet prostředí podněcující spolupráci, koučovat/vést žáky, podporovat je při hledání neznámé metody řešení a klást otázky (Proč?, Jak byste to vysvětlili?, Je to opravdu tak?, Znáte nějaký podobný problém/úlohu?, Jakou zajímavou otázku ještě můžeme položit? apod.). Učitel působí proaktivně, podporuje úsilí žáků, hodnotí přínos žáků (včetně chyb, kterých se dopustili) a posouvá je v učení pomocí jejich vlastních zjištění a interpretací.

Revidovaná verze National Science Educational Standards (NRC, 2000) se problematice bádání věnuje podrobněji a rozlišuje dva typy bádání - plné a částečné podle toho, jakou měrou jsou do něj žáci zapojeni. Některé studie jsou ještě důkladnější a rozlišují více úrovní bádání (např́iklad Fradd et al., 2001), viz tab. 1.

Tab. 1: Úrovně bádání dle rozdělení badatelských aktivit mezi učitele (U) a žáky (Ž)

\begin{tabular}{|c|c|c|c|c|c|c|c|}
\hline $\begin{array}{l}\text { Uroveň } \\
\text { bádání }\end{array}$ & $\begin{array}{l}\text { Kladení } \\
\text { otázek }\end{array}$ & $\begin{array}{c}\text { Plánování } \\
\text { postupů }\end{array}$ & $\begin{array}{l}\text { Realizace } \\
\text { plánů }\end{array}$ & $\begin{array}{c}\text { Analýza } \\
\text { dat }\end{array}$ & $\begin{array}{l}\text { Vyvozování } \\
\text { závěrů }\end{array}$ & $\begin{array}{l}\text { Přednesení } \\
\text { zprávy }\end{array}$ & $\begin{array}{l}\text { Uplatnění } \\
\text { poznatků }\end{array}$ \\
\hline 0 & $\mathrm{U}$ & $\mathrm{U}$ & $\mathrm{U}$ & $\mathrm{U}$ & $\mathrm{U}$ & $\mathrm{U}$ & $\mathrm{U}$ \\
\hline 1 & $\overline{\mathrm{U}}$ & $\overline{\mathrm{U}}$ & $\overline{\mathrm{U} / \check{Z}}$ & $\overline{\mathrm{U}}$ & $\bar{U}$ & Ž & $\overline{\mathrm{U}}$ \\
\hline 2 & $\overline{\mathrm{U}}$ & $\overline{\mathrm{U}}$ & $\bar{Z}$ & $\bar{U} / \check{Z}$ & $\bar{U} \mathrm{U} / \mathrm{Z}$ & Ž & $\overline{\mathrm{U}}$ \\
\hline 3 & $\mathrm{U}$ & $\mathrm{U} / \check{\mathrm{Z}}$ & $\check{Z}$ & $\check{Z}$ & $\check{Z}$ & Ž & $\check{Z}$ \\
\hline 4 & $\mathrm{U} / \check{\mathrm{Z}}$ & $\check{Z}$ & $\check{Z}$ & $\check{Z}$ & $\check{Z}$ & $\check{Z}$ & $\check{Z}$ \\
\hline 5 & $\overline{\mathrm{Z}}$ & $\overline{\mathrm{Z}}$ & $\bar{Z}$ & $\bar{Z}$ & $\bar{Z}$ & $\bar{Z}$ & $\bar{Z}$ \\
\hline
\end{tabular}

Stuchlíková (2010: s. 132) uvádí podle (Eastwell, 2009) také několik úrovní bádání:

- potvrzující bádání - otázka i postup jsou žákům poskytnuty, výsledky jsou známy, jde o to je vlastní praxí ověřit;

- strukturované bádání - otázku i možný postup sděluje učitel, žáci na tomto základě formulují vysvětlení studovaného jevu;

- nasměrované bádání - učitel dává výzkumnou otázku, žáci vytvářejí metodický postup a realizují jej;

- otevřené bádání - žáci si sami kladou otázku, promýšlejí postup, provádějí výzkum a formulují výsledky.

\section{BOV V MATEMATICKÉM VZDĚLÁVÁNÍ}

Na úvod tohoto oddílu bychom rádi upozornili, že zde uváděné charakteristiky BOVM jsou platné výhradně v evropském kontextu. Mimo Evropu je vztah bádání a matematického vzdělávání mnohdy chápán jinak, podrobný rozbor však přesahuje záměry tohoto článku. ${ }^{6}$

V matematickém vzdělávání očekáváme, že BOV přispěje nejen k formování badatelských návyků, ale především ke zlepšení porozumění matematickým pojmům a postupům. BOV tedy chápeme jako cestu i jako cíl matematického vzdělávání. Takové porozumění je předpokladem pro získání znalostí „ppoužitelných“ v různých

\footnotetext{
${ }^{6}$ Například v severoamerickém kontextu se bádání vztahuje výhradně k přírodovědným předmětům (Schoenfeld \& Kilpatrick, 2013).
} 
kontextech i mimo běžné školní prostředí. Tento požadavek se odvíjí od faktu, že matematika se využívá v různých společensko-vědních oborech, a tím vstupuje téměř do všech oblastí lidské činnosti. Mnoho každodenních záležitostí může být uchopeno prostřednictvím matematiky kombinované s přírodovědnými předměty nebo se „zdravým rozumem" a tyto záležitosti jsou bohatým zdrojem pro badatelsky orientované aktivity zejména na prvním a druhém stupni základní školy. Nelze opomenout ani matematické objekty jako takové (čísla, proměnné, geometrické tvary aj.), které jsou základním zdrojem matematického bádání - i takové bádání by mohlo a mělo být zařazováno do školní matematiky.

V souvislosti s BOVM se také zdưrazňuje význam vytvoření přesnější představy o matematice jako lidské aktivitě, chápání matematiky jako základní součásti kulturního dědictví a ocenění klíčové role, kterou hrála a hraje v rozvoji společnosti.

Badatelsky orientované vyučování matematice odkazuje na vzdělávání, které studentům a žákům neprezentuje matematiku jako hotovou strukturu určenou k osvojení. Spíše jim nabízí příležitost zažít:

- jak se tvoří matematické znalosti prostřednictvím osobních i kolektivních pokusů odpovědět na otázky objevující se v různých sférách lidské činnosti, od pozorování př́rody až po matematiku jako takovou;

- jak mohou matematické pojmy a struktury vzniknout z výsledných konstrukcí a být dále využivány k zodpovězení nových a náročných problémů. (Artigue et al., 2011: s. $8^{7}$, vlastní překlad)

\section{Z předchozího pak vyplývá vymezení BOVM:}

Podobně jako bádání v přírodovědných předmětech, také bádání v matematice začíná otázkou nebo problémem, přičemž odpovědi hledáme pozorováním a zkoumáním; realizujeme mentální, skutečné nebo virtuální experimenty; hledáme další, již dříve řešené a vyřešené zajímavé otázky a problémy, které jsou podobné těm našim; používáme a přizpưsobujeme, je-li to potřeba, známé matematické techniky. Proces bádání je veden nebo vede $\mathrm{k}$ hypotetickým odpovědím - domněnkám, které je potřeba ověřit. (Artigue \& Baptist, 2012: s. $4^{8}$, vlastní překlad)

\footnotetext{
${ }^{7} \mathrm{~V}$ původním znění: „Inquiry-based mathematics education refers to an education which does not present mathematics to pupils and students as a ready-built structure to appropriate. Rather it offers them the opportunity to experience:

- how mathematical knowledge is developed through personal and collective attempts at answering questions emerging in a diversity of fields, from observation of nature as well as the mathematics field itself, and,

- how mathematical concepts and structures can emerge from the organisation of the resulting constructions, and then be exploited for answering new and challenging problems."

${ }^{8} \mathrm{~V}$ původním znění: „Like scientific inquiry, mathematical inquiry starts from a question or a problem, and answers are sought through observation and exploration; mental, material or virtual experiments are conducted; connections are made to questions offering interesting similarities with the one in hand and already answered; known mathematical techniques are brought into play and adapted when necessary. This inquiry process is led by, or leads to, hypothetical answers - often called conjectures — that are subject to validation."
} 
Jako základní znaky výuky zaměřené na bádání jsou představovány:

- úlohy a otázky, které mohou být různě interpretovány, mají více způsobů řešení, více správných odpovědí;

- objevování a znovuobjevování (jako doplněk k deduktivnímu př́ístupu);

- učení se z chyb (hlavně vlastních, ale i cizích; chyba je chápána jako nedílná součást učebního procesu) $;^{9}$

- zajištění dostatečně husté sítě základních znalostí (na nichž by bylo možné dále stavět);

- kumulativní styl učení (propojování nových poznatků s dřive nabytými znalostmi);

- propojení matematiky s jinými obory (i nevšedními, např. českým jazykem či dějepisem);

- podpora kooperativního i autonomního učení. (srov. Artigue \& Baptist, 2012: s. $13-14)$

Zdrojem matematického bádání při výuce mohou být:

- př́rodní jevy (Jak a proč se mění stín předmětu osvětleného sluncem?);

- technické problémy (Jak změřit objekt, který je nedostupný?);

- každodenní problémy (Který telefonní tarif je pro mě nejvhodnějšíi?);

- lidské vynálezy (Jak funguje GPS?);

- umění (Které symetrie jsou v architektonickém nebo uměleckém díle?);

- a samozřejmě matematické objekty (Mám-li dva trojúhelníky stejného obsahu, mohu jeden rozstříhat a poskládat z něj druhý?). (srov. Artigue \& Baptist, 2012: s. 5)

K vytvoření správné představy o povaze vědy je možné podobně jako v prř́rodovědných předmětech využít řešení otevřených problémů a diskuse nad pozorováními a jejich různými interpretacemi. Kniha (McComas, 1998) je sice primárně určena pro přírodovědné vzdělávání, ale mnoho podnětů zde uvedených je univerzálních, využitelných pro vytvoření představy o povaze vědy v libovolném vědeckém oboru. Doporučujeme zejména kapitolu (Lederman \& Abd-El-Khalick, 1998), aktivity Ošemetné stopy (s. 85-91) a Děrovaný obrázek (s. 91-95).

\section{BOVM V DIDAKTICE MATEMATIKY}

Základní myšlenky BOV je možné najít v dílech Johna Deweye (zejména Dewey, 1938). Nicméně první náznaky je možné hledat i u jeho předchůdců, z nichž jmenujme alespoň Humboldta, Pestalozziho a Fröbela, kteří hledali cesty, jak zakládat vědomosti na myšlení, experimentování a reflexi, jak stimulovat zájem žáků o učení a kultivovat jejich autonomii. Ještě hlouběji z minulosti je možné připomenout řeckého filozofa Sokrata a jeho dialogickou metodu tázání.

Jak již bylo řečeno, teoretický základ badatelsky orientovaného vyučování bývá zpravidla spojován s myšlenkami amerického filozofa a pedagoga Johna Deweye. Pro Deweye je bádání základem jak pro objevování nového, tak i pro učení již objeveného. Vymezuje bádání jako

\footnotetext{
${ }^{9} \mathrm{~V}$ českém prostředí se chybě jako edukační strategii věnuje Hejný (2004).
} 
kontrolovanou nebo řízenou transformaci neurčité situace v situaci, která je určitá do té míry, nakolik to vyžaduje zařazení prvků původní situace do nějakého jednotného celku. (Dewey, 1938: s. 104-105 ${ }^{10}$, vlastní překlad)

V navazujícím textu pak toto vymezení objasňuje:

Ta počáteční neurčitá situace není pouze „otevřená“ bádání, ale je také otevřená v tom smyslu, že její součásti nedrží pohromadě.

Neurčité situace mohou být charakterizovány různými pojmenováními. Jsou znepokojivé, svízelné, nejednoznačné, popletené, plné protichůdných tendencí, mlhavé, apod. (Dewey, 1938: s. 105¹1, vlastní překlad)

Proces bádání se vyvíjí jako souhra známého a neznámého v situacích, kdy se jednotlivec nebo skupina jednotlivců potýkají s nějakou výzvou. Je potřeba, aby situace obsahovala neznámé vnímané jako podnětné nebo zajímavé; přičemž bádání je možné, pouze pokud $\mathrm{k}$ této neznámé části mưžeme přistupovat prostřednictvím věcí již známých, protože pouze fakta a souvislosti mohou vést $\mathrm{k}$ domněnkám a úsudkům. Dewey vidí učení jako adaptivní proces, při kterém je zkušenost hnacím motorem pro vytváření spojení mezi pocity a myšlenkami, prostřednictvím kontrolovaného a reflexivního procesu nazvaného reflexivní bádání (reflective inquiry; Dewey, 1938). To znamená, že jde o interakce mezi individuem a jeho okolím: bádání není chápáno jako vědecká aktivita, ale spíše jako vyrovnávání se s každodenními požadavky.

Artigue a Blomhøj (2013) vyhodnocují Deweyův přínos jako podstatný a zejména zdůrazňují, že bádání je procesem, který je určen objektem nebo problémem, který je zkoumán, at se týká každodenního života, praxe nebo „vědeckých“ aktivit. Tento proces zahrnuje indukci a dedukci a je přirozeně reflexivní, neliší se podstatně v různých kontextech a rozvíjí zpơsoby učení. Znalosti a zkušenosti, které v činnosti používáme a získáme, jsou efektivní a přenositelné do jiných situací a kontextů.

Za téměř století, které uběhlo od uveřejnění Deweyovy knihy, si myšlenka vyučování založeného na bádání postupně našla cestu do př́írodovědného vzdělávání, a to jako součást učení objevováním, aktivizujících metod učení, projektové metody apod., a ovlivnila i matematické vzdělávání. Vznikly různé teoretické rámce, které se odvolávají na Deweyovy myšlenky (podrobně v Artigue \& Blomhøj, 2013). V českém kontextu mají vliv zejména: učení řešením úloh a problémů, teorie didaktických situací, realistické matematické vzdělávání, matematické modelování, uchopování situací, tvoření úloh (problem posing), projektové metody, podnětná výuková prostředí a budování schémat, konstruktivistické př́stupy k vyučování. Podle našeho soudu BOVM tyto teoretické rámce zastřešuje. BOVM má určité charakteristiky (viz obr. 1), které jednotlivé rámce různě intenzivně využivají.

$\mathrm{V}$ dalším textu jsou podrobněji zmíněny některé jejich charakteristiky a souvislosti s BOVM.

\footnotetext{
${ }^{10} \mathrm{~V}$ původním znění: ,... the controlled or directed transformation of an indeterminate situation into one that is so determinate in its constituent distinctions and relations as to convert the elements of the original situation into a unified whole."

${ }^{11} \mathrm{~V}$ původním znění: „The original indeterminate situation is not only "open” to inquiry, but it is open in the sense that its constituents do not hang together. A variety of names serves to characterize indeterminate situations. They are disturbed, troubled, ambiguous, confused, full of conflicting tendencies, obscure, etc."
} 


\subsection{UČENÍ ŘEŠENÍM ÚLOH A PROBLÉMŮ}

Učení řešením úloh a problémů vychází zejména z Polyových prací (1945, 1962). S BOVM se částečně překrývá; v některých evropských projektech se dokonce vymezení BOVM na řešení problémů redukuje (např. projekt ASSIST-ME).

Souvislost obou přístupů je zjevná: žáci čelící nerutinním úlohám a problémům musejí rozvíjet své vlastní strategie a techniky, během jejich řešení provádějí činnosti, které jsou podobné činnostem prováděným při bádání. Nehraje roli, zda úlohy a problémy vycházejí přímo z matematického obsahu nebo matematiku při svém řešení využívají. Rozvoj schopnosti řešit problémy je často považován za cíl sám o sobě, nemusí nutně souviset s výukou specifických pojmů a technik, důraz je kladen na metakognici a heuristiku. Cai (2010) shrnuje, že při výuce matematiky realizované prostřednictvím řešení úloh a problémů začíná výuka zkoumáním problémů, které by mohly umožnit žákům naučit se a pochopit důležité aspekty nějakého matematického pojmu. Problémy bývají otevřené, mají více správných postupů řešení, více správných odpovědí. Žáci řeší problém individuálně, s větší či menší mírou individuální pomoci učitele (učitel funguje jako facilitátor, prostřednictvím návodných otázek směruje žákovu aktivitu). Poté probíhá široká diskuse nad jednotlivými postupy a výsledky, která žákům odhaluje alternativní přístupy a umožňuje jim vyjasnit si své myšlenky. Na závěr učitel stručně shrne situaci a vede žáky k pochopení klíčových aspektů pojmu založeného na daném problému a jeho vícečetném řešení. Výuka pak pokračuje postupným osamostatňováním žáků při řešení dalších problémů.

$\mathrm{Z}$ výše uvedené charakteristiky je vidět, že pedagogický přístup k bádání a k řešení problémů i výzkum těchto oblastí se překrývají a my můžeme výsledky výzkumu z oblasti řešení problémů využívat v BOVM. Jak vyplývá z Schoenfeldova (1992) shrnutí, výzkum v oblasti řešení problémů se především zajímá o identifikaci a rozvoj schopností a myšlenkových návyků, které umožní žákům stát se úspěšnými řešiteli problémů, schopnými efektivně čelit nerutinním a náročným problémům.

V klasifikaci uvedené $\mathrm{v}$ tab. 1 bychom takovou výuku nejprve zařadili do úrovně 1 nebo 2, s postupujícím osamostatňováním žáků je možno dosáhnout až úrovně 5 .

Poznamenejme, že u nás byly na toto téma vydány knihy (Vyšín, 1972; Kuřina, 1976). Z novějších publikací uved’me Kư̌inův článek (2005), který se významu učení řešením problémů věnuje $\mathrm{v}$ zajímavých souvislostech.

\subsection{TEORIE DIDAKTICKÝCH SITUACÍ (TDS)}

V teorii didaktických situací (Brousseau, 1997, česky 2012) je centrálním pojmem didaktická situace. Ta je definována jako systém, ve kterém probíhá interakce mezi žákem/skupinou žáků, učitelem a matematickou znalostí. Specifickým typem této situace je a-didaktická situace (viz obr. 2), v níž učitel umožní, aby žáci získali novou vědomost ve vyučování bez jeho explicitní intervence. Situace je navozena řešením úloh, které jsou pod kontrolou učitele. Devoluce znamená, že žáci mají úlohy vzít za vlastní, přijmout odpovědnost za jejich řešení. Není pochyb o tom, že si žák zvyká na samostatné objevování, badatelské aktivity ale nejsou primárně cílem.

Na rozdíl od učení řešením úloh a problémů, kde žáci nejprve pracují individuálně a až poté diskutují nad svými výtvory, v teorii didaktických situací se předpokládá, že žáci budou diskutovat již od samého počátku řešení a nová matematická znalost jimi bude kolektivně vystavěna během diskuse. Matematická znalost se objevuje jako optimální řešení úlohy v interakci s vhodným prostředím, od žáků se očekává, že ji budou vytvářet kolektivně, úpravami, příp. i odmítnutím jejich vlastních pů- 


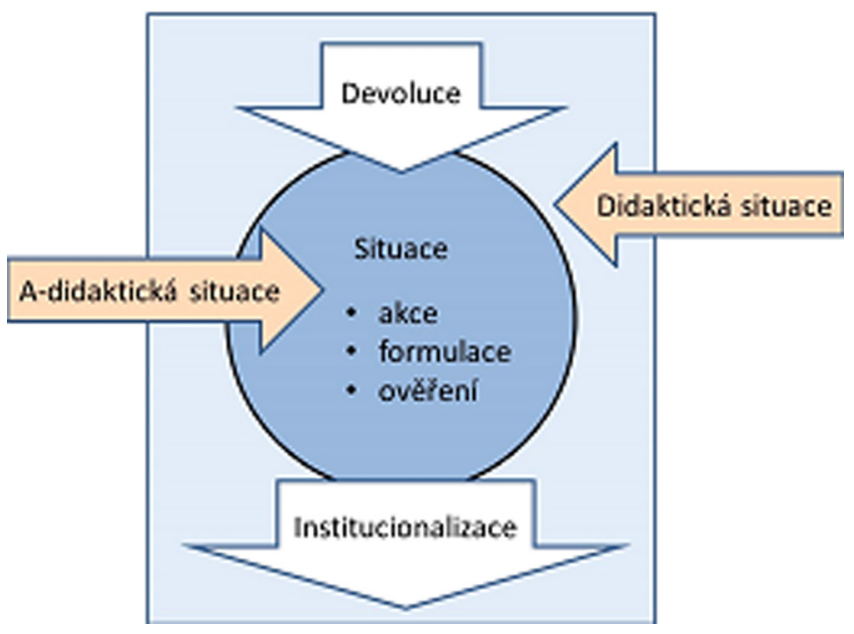

Obr. 2: Teorie didaktických situací; upraveno podle (Novotná \& Hošpesová, 2013)

vodních strategií. V ideálním př́ípadě učitel pouze iniciuje a usměrňuje diskusi, na úrovni poznatků do diskuse vůbec nezasahuje a na závěr diskuse institucionalizuje její výsledky.

Z pohledu klasifikace uvedené v tab. 1 patří aktivity se samostatnou diskusí žáků až do nejvyšších dvou úrovní (4 a 5), tuto obtížnost zpočátku vyvážíme výběrem méně náročného tématu $\mathrm{k}$ diskusi.

U nás se didaktickým situacím v matematice věnuje skupina kolem Novotné (Novotná et al., 2006; Nováková, 2013).

\subsection{REAlistickÉ MATEMATiCKÉ VZDĚLÁVÁNí}

Realistické matematické vzdělávání (RMV) odkazuje na vyučování, během kterého je matematika součástí žákovy reality, at už skutečné nebo uměle vytvořené. Situace odehrávající se v této realitě mohou být brány z každodenního života stejně jako z čistě matematického prostředí, nebot matematické objekty se postupně stávají součástí žákovy reality. Klíčovým principem RMV je řízené objevování a znovuobjevování (Freudenthal, 1973, 1991), při němž si žáci vytvářejí vlastní „matematiku“" a postupně z neformálních strategií řešení úloh přecházejí $\mathrm{k}$ formalizovanějším metodám.

Hlavní činností při RMV je matematizace. Treffers (1987) rozlišuje matematizaci horizontální a vertikální: horizontální matematizace odkazuje na transformaci každodenních problémů do řeči matematiky, zatímco vertikální matematizace se týká transformací v rámci matematického systému.

U nás se řízeným objevováním a znovuobjevováním zabýval Vyšín (1976). Poukázal na znovuobjevování jako součást tzv. genetického stylu vyučování. Zabýval se i psychologickou složkou tohoto stylu výuky:

Naprostá většina mladých lidí netouží po „matematice pro labužníky“, jejíž těžiště je např. v elegantních důkazech, v logické stavbě, ale touží dovědět se něco nového, netriviálního, dostat do rukou účinný aparát, kterým mohou rozřešit zajímavé problémy. Tuto touhu může genetické vyučování plně uspokojit. Vyučování organizované genetickým stylem má nesporně nejlepší předpoklady pro výchovnou stránku: učí překonávat překážky, neobcházet je, učí systematické práci, plánování, kri- 
tičnosti, vytrvalosti, rozumné zvídavosti, odvyká povrchnosti, pasivitě.

(Vyšín, 1976: s. 588)

V 70. letech 20. století se tento styl výuky objevil i na školách, kde řídil vyučování matematice Kabinet pro modernizaci vyučování matematice MÚ ČSAV, jako součást tzv. matematické laboratoře:

Byla tu řeč o matematické laboratoři jako o jisté organizaci procesu učení na pokusných školách Kabinetu. Tímto názvem míníme takovou organizaci výuky, kde se maximálně uplatní metody aktivizující žáky: jde zejména o experimentování, o tzv. genetický př́stup, při kterém učitel funguje jako činitel řízeného objevování, o problémové vyučování v nejobecnějším pojetí, kde se nejen poznatky získávají jako výsledky řešení úloh, ale kde se i rozvíjejí problémové situace a matematizují situace z reálného světa. (Vyšín, 1979: s. 107)

RMV má s BOVM společné zejména chápání matematiky jako lidské aktivity a snahu o to, aby matematika byla (znovu)objevována. Žák provádí rekonstrukci matematických pojmů a rozvíjí je přirozeným způsobem v dané problémové situaci. Důležité je vedení (knihami, spolužáky, učitelem) a postupné přibližování se běžnému matematickému standardu.

Vzhledem $\mathrm{k}$ výše uvedenému může z pohledu klasifikace uvedené v tab. 1 úroveň bádání při realistickém matematickém vyučování dosáhnout úrovní 1 až 5 .

\subsection{MatematickÉ MODELOVÁNí}

Matematické modelování hraje podstatnou roli při konceptualizaci poznatků, a tak ve výzkumu matematického vzdělávání získává stále větší pozornost (Kaiser et al., 2011). Blomhøj a Jensen (2003) popisují proces tvorby matematického modelu, který probíhá v šesti základních fázích:

(i) Formulace problému (více či méně explicitní), která vede k identifikaci charakteristik reality, jež má být modelována.

(ii) Výběr relevantních objektů a vztahů z původní oblasti bádání a jejich idealizace tak, aby byla umožněna matematická reprezentace.

(iii) Převod těchto objektů a vztahů z oblasti jejich původního výskytu do matematiky.

(iv) Využití matematických metod k dosažení matematických výsledků a závěrů.

(v) Jejich převod do původní oblasti bádání.

(vi) Vyhodnocení platnosti modelu ve srovnání s pozorovanými či předpokládanými daty nebo s teoreticky podloženými znalostmi. (Blomhøj \& Jensen, 2003: s. 125)

Proces tvorby modelu není lineární, v libovolné fázi mohou nastat obtíže, které si vynutí ústup zpět do bodu (iii), (ii) nebo (i). Těmito obtížemi může být např. neproveditelnost převodů (do nebo z matematiky), neřešitelnost nebo př́lišná obtížnost matematické úlohy v bodu (iv), negativní vyhodnocení platnosti modelu.

V matematickém modelování se při řešení složitějších problémů často využívají počítače. Vhodně zvolený matematický software dokáže nabídnout alternativní řešení fáze (iv) nebo některé její části v př̌ípadě, kdy použití běžného matematického aparátu by bylo př́liš obtížné či nemožné (Samková, 2011, 2013; srov. Samková, 2012a). 
Ve vztahu k BOVM znamená matematické modelování cestu k porozumění, vytváření vztahu mezi matematickou a problémovou situací. Matematické modelování tak může vést $\mathrm{k}$ pochopení bádání jako obecnějšího procesu s různými specifickými realizacemi v kontextu různých disciplín.

Pohled matematického modelování na výuku matematiky je v souladu s Deweyovým požadavkem vycházet $\mathrm{z}$ problémů skutečného života a stavět na žákovských zkušenostech.

I zde může $\mathrm{z}$ pohledu klasifikace uvedené $\mathrm{v}$ tab. 1 úroveň bádání dosáhnout úrovní 1 až 5.

\subsection{DALŠí TEORETICKÉ RÁMCE}

Uchopování situací - Uchopováním situací máme na mysli tyto myšlenkové procesy: vnímání situace; objevení klíčových objektů, jevů a vztahů; stanovení určitého směru uchopování zaměřeného na určité téma, pojem nebo na metodu řešení; vytvoření modelu, který umožní formulování otázek a tvoření úloh. Tomuto př́istupu se věnovali např. Koman a Tichá (1995, 1996a, 1996b), Tichá a Koman (2000).

Tvoření úloh (problem posing) - Potřeba rozvíjení dovednosti tvořit úlohy je často uváděna $\mathrm{v}$ souvislosti $\mathrm{s}$ uplatňováním otevřeného přístupu v matematickém vyučování a v souvislosti s otázkami kolem matematizace reálných situací. Významnou roli zde hraje problematika vytváření zásoby různých modů reprezentací a překladů mezi nimi pro prohlubování poznání. V českém prostředí se této tematice věnují např. Tichá a Hošpesová (2011, 2014), Tichá (2014), Patáková (2013), Bureš (2014).

Projektová metoda - Při vyučování projektovou metodou jsou žáci vedeni k samostatnému zpracovávání určitých témat (projektů) a získávají zkušenosti praktickou činností a experimentováním (Průcha, Walterová \& Mareš, 2009). Pro školní matematiku připomeňme publikaci Kubínové (2002).

Podnětná výuková prostředí a budování schémat - Na myšlenky Deweye, Piageta a Freudenthala navázal také Wittmann (2001), když stanovil požadavky na tzv. podnětná výuková prostředí (substantial learning environments): prostředí, která umožňují formulovat série úloh a problémů, jež žákovi pomohou pochopit hluboké matematické myšlenky. Tato podnětná výuková prostředí používá Wittmann mj. k výuce zacílené na matematizaci, argumentaci, komunikaci a učení objevováním. U nás byla myšlenka podnětných výukových prostředí zpracována např. v monografiích (Stehlíková, 2007; Hejný, 2014) a stala se i teoretickým východiskem řešení projektu Comenius Motivation via Natural Differentiation in Mathematics (Hošpesová et al., 2010). Podnětná výuková prostředí umožňují budování schémat, souborů generických a izolovaných modelů nějakého matematického objektu a souborů vazeb mezi těmito modely. Rolí schémat v matematickém vzdělávání a jejich budování se věnovali v návaznosti na Piageta již Skemp (1971) či Fischbein (1999), v českém prostředí Hejný (2007).

Konstruktivistické př́stupy $k$ vyučování - Hlavním znakem konstruktivistických př́istupů k vyučování matematice je aktivní vytváření části matematiky v mysli žáka. Podle povahy žáka může být podkladem pro takovou konstrukci otázka či problém ze světa př́rody, techniky nebo matematiky samé. V českém prostředí tuto tematiku rozpracovali napr. Kuřina (2002); Hejný a Kuřina (2009); Stehlíková (2004); Stehlíková a Ulrychová (2011).

Myšlenky, které by se daly interpretovat jako podněcující k badatelským aktivitám žáků, se dají nalézt i u Komenského ve spisu Didactica Magna-v kapitole XVII, odst. 44 mluví o neurčitosti následovně: 
Usnadníš tedy žáku práci, jestliže mu při všem, čemu ho budeš učit, ukážeš, jak se toho užívá v denním životě. To musí býti naprosto všude, $\mathrm{v}$ mluvnici, v dialektice, aritmetice, geometrii, fysice atd. Nestane-li se tak, všecko, co mu vyložíš, bude se mu zdáti nějakými zjevy z Nového světa; a chlapec, jenž se nestará, jsou-li ve skutečnosti takové věci a jak jsou, bude v ně spíše věřit, nežli o nich vědět. Ukážeš-li však, k čemu všecko slouží, umožníš mu zcela, aby si byl vědom své znalosti a snažil se ji uplatnit. (Komenský, 1948: s. 124)

\section{TEORETICKÝ MODEL PROCESU BÁDÁNÍ}

Východiskem pro badatelské aktivity žáků v matematickém vzdělávání je vytvoření vhodného prostředí. To je obvykle dáno úlohou nebo problémem, který mají žáci řešit.

Úlohy, při jejichž řešení lze očekávat badatelské aktivity, jsou rozmanité. Vyšli jsme z Deweyova vymezení bádání a nejprve jsme vzali v úvahu „neurčitost situace“. Úlohy mohou být zadány více či méně neurčitě, a dávat tak větší či menší prostor k badatelským aktivitám.

Pokusili jsme se o vytvoření teoretického modelu, který podle našeho názoru vystihuje podstatu a možnosti badatelských aktivit. Znázornili jsme tuto myšlenku prostřednictvím diagramu na obr. 3 vlevo: černé čáry znázorňují všechny existující cesty vedoucí od vstupní situace k situaci výstupní. Každá cesta je tvořena posloupností kroků, které transformují vstupní situaci v situaci výstupní. Záleží na žákovi, zda nějakou cestu od vstupu k výstupu dokáže najít, na kolika křižovatkách znázorněných fialovými kolečky se dokáže (správně) rozhodnout o pokračování cesty. Pokud se na křižovatce setká s věcmi neznámými nebo pro něj příliš obtížnými, musí se vrátit a zkusit jinou cestu.
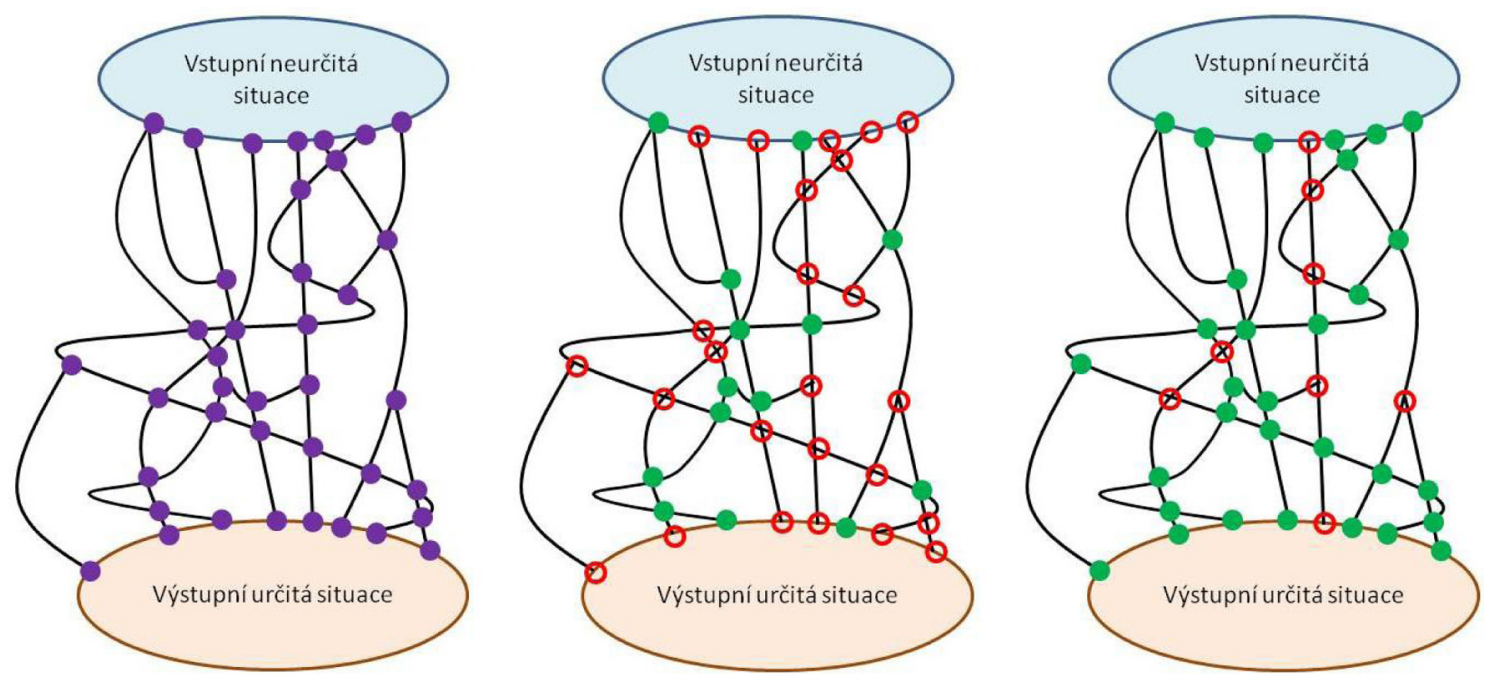

Obr. 3: Teoretický model procesu bádání - obecný nákres (vlevo), slabý žák (uprostřed), talentovaný žák (vpravo)

Badatelsky zdatnější žáci jsou schopni odhalit i více než jednu cestu. Na učiteli záleží, jak velký prostor pro manévrování žákům nechá. Pokud je úloha sestavena př́liš určitě, vede od vstupu k výstupu pouze jedna cesta a o bádání se nejedná. Pokud je úloha sestavena prŕliš neurčitě, vede od vstupu k výstupu mnoho cest, 
které se různě kř̌iží, a řešení úlohy může být př́liš časově náročné. Pokud je žák slabý nebo je úloha sestavena neúměrně $\mathrm{k}$ jeho znalostem, může se stát, že žák skončí někde „mezi“ - není schopen najít žádnou cestu, přestože existuje. V takovém případě by žák neměl úlohu mylně zakončit závěrem, že žádné řešení neexistuje. Je na učiteli, aby vhodným způsobem pomohl žákovi cestu nalézt; může se například žákovi věnovat individuálně a pokládat mu návodné otázky nebo k tomuto účelu využít tř́ídní diskusi. Žáci by si měli být vědomi rozdílu mezi neexistencí řešení a neschopností řešení nalézt. Měli by vědět, že neexistenci řešení nebývá snadné dokázat. Obecně je možné k takovému závěru dojít až po nalezení a vyzkoušení všech možných cest, a křižovatek a zjištění, že žádná z cest od vstupu k výstupu nevede. Řešitel je však málokdy schopen nalézt a vyzkoušet všechny takové možnosti, může mít také problémy s ověřením, že vyčerpal skutečně všechny. A tak se $\mathrm{k}$ důkazu neexistence řešení častěji používá porovnání vstupu a výstupu a zjištění, že jsou natolik odlišné, že mezi nimi žádná cesta existovat nemůže.

Shrnuto: o složitosti badatelské úlohy rozhoduje množství cest, které mezi vstupem a výstupem existují, a úroveň znalostí žáka na jednotlivých cestách. Učitel by měl úlohu vybírat tak, aby byla úměrná znalostem žáka a aby umožňovala bádání $\mathrm{v}$ přiměřeném rozsahu.

Zde se ukazuje náročnost př́prav na BOV. Učitel by si měl ideálně ke každé badatelské úloze nakreslit podobné schéma jako na obr. 3 vlevo - nemusí být vykresleno dopodrobna se všemi detaily, stačí si vyznačit „křižovatky, které žáci nejspíš znaji“ a zkontrolovat, že počet a podoba cest vedoucích přes tyto „známé“ křižovatky odpovídají učebnímu záměru (časová náročnost, probírané učivo, zapojení slabších žáků, vytížení talentovaných žáků apod.).

Obr. 3 uprostřed ukazuje dobře sestavenou badatelskou úlohu z pohledu slabého žáka, „známé“ křižovatky jsou označeny plnými zelenými kolečky, „,neznámé“ prázdnými červenými kolečky. Ze 7 vstupních možností zná žák pouze 2 , ale u té druhé se jedná o izolovanou znalost. Ve schématu existuje cesta od vstupu k výstupu jdoucí pouze přes zelené křižovatky, žák má tedy šanci dobrat se řešení. Cesta se na jednom místě rozdvojuje a jedna z možností se posléze ukáže jako slepá, takže i pro tohoto slabšího žáka je úlohou podněcující bádání. Schéma obsahuje několik izolovaných zelených bodů, které žák sice zná, ale při řešení je nepoužije. Jeden z nich je přímo ve výstupu - žák tedy zná jedno z řešení, ale neví o tom (není schopen dokázat, že je to řešení).

Obr. 3 vpravo ukazuje tutéž úlohu z pohledu talentovaného žáka. Pouze jediné řešení není tento žák schopen odhalit, protože $\mathrm{k}$ němu ještě nemá dostatečné znalosti (ale izolované části této cesty již zná - je to pro něj výzva). Na ostatních cestách se izolovaně vyskytují červená kolečka, ale není jich dost na to, aby zabránila odhalení cesty - vždy existuje nějaká zelená oklika.

Tento teoretický model v současné době ověřujeme.

\section{NÁMĚTY ÚlOH, KTERÉ MOHOU VÉST K BADATELSKÝM AKTIVITÁM ŽÁKŮ}

Ilustrujme předchozí myšlenky o uplatnění badatelského prrístupu ve školské matematice prostřednictvím několika úloh s různým matematickým obsahem.

Úlohy, které mohou vést $\mathrm{k}$ badatelské aktivitě žáků, souhrnně nazveme badatelské úlohy. Jsou to úlohy otevřené ve smyslu otevřeného př́istupu k výuce mate- 
matiky (viz oddíl 1). Použití badatelské úlohy ve výuce samo o sobě nezaručuje, že k badatelské aktivitě žáků skutečně dojde. Toho lze dosáhnout pouze dodržením charakteristik uvedených na obr. 1.

Východiskem našich úvah o úlohách, které mohou vést $\mathrm{k}$ badatelským aktivitám žáků, bylo Deweyovo vymezení bádání. Na jeho základě jsme se pokusili badatelské úlohy roztř́ídit. Uvědomujeme si, že náš výčet typů badatelských úloh není vyčerpávající, doufáme však, že se stane inspirací pro hledání typů dalších. V souladu s Kuřinovým přístupem $(2005)^{12}$ si dovolujeme charakteristiky jednotlivých typů badatelských úloh podpořit větším množstvím rozmanitých příkladů. U těchto př́́kladů přednostně sledujeme obsahový cíl. Učební cíl si musí učitel zvolit sám, stejně tak jako musí vybranou badatelskou úlohu přizpůsobit konkrétní skupině žáků, se kterou ji chce řešit (jejich schopnostem, znalostem). U jednotlivých úloh neuvádíme podrobná řešení, pouze poukazujeme na zajímavé aspekty související s jejich matematickým obsahem či s metodou řešení a odkazujeme na př́padné české publikace, které se uvedeným úlohám a úlohám jim podobným věnují podrobněji.

Ulohy nebo jejich části, které jsou vhodné již pro žáky na 1 . stupni ZS̆, ${ }^{13}$ označujeme v záhlaví jednou hvězdičkou - *. Tyto úlohy můžeme samozřejmě začlenit i do vyučování na vyšších stupních škol; at již v nezměněné podobě, nebo obohacené o nové otázky. Z pohledu teoretického modelu (obr. 3) znají starší žáci či studenti více křižovatek, a tak bude velice pravděpodobně existovat více cest k objevování. Jinak řečeno, při řešení úlohy se staršími žáky a studenty se mohou uplatňovat nové (neprvostupňové) metody řešení a mohou být nalezena nová řešení.

Části úloh, které jsou pro žáky 1. stupně přiliš obtížné (z hlediska používaných pojmů nebo potřebných postupů) a jsou vhodné až pro žáky 2. stupně, označujeme dvěma hvězdičkami - **. Domníváme se, že při jejich začlenění do výuky na 1 . stupni by pravděpodobně nebyl plně využit jejich potenciál.

Části úloh, které jsou př́liš obtížné i pro žáky 2. stupně, označujeme třemi hvězdičkami - ${ }^{* * *}$. V tomto článku jsou uvedeny hlavně pro učitele a didaktiky matematiky, aby si mohli udělat lepší představu o obsahovém cíli př́islušné úlohy a sami si mohli vyzkoušet bádání s vyšší obtížností.

Učitel se musí sám rozhodnout, ve kterém ročníku kterou úlohu využije a proč. Při tomto rozhodování není až tak důležitý věk žáků, ale hlavně zvolený učební cíl. To znamená, že učitel musí být schopen si uvědomit, jaká témata a metody řešení se danou úlohou mohou rozvíjet, a posoudit, zda jsou v souladu s jeho učebním plánem.

Je-li badatelská úloha zadána ve formě slovní úlohy, tak vstupní situaci badatelského procesu určují podmínky slovní úlohy, výstupní situaci určují otázky. Úlohy s jednou podmínkou a jednou otázkou budeme nazývat jednoduché badatelské úlohy. Třídit je budeme podle množství informací, které určují vstupní situaci - vstupních informací. Toto množství může být obecně různě velké, ale pro badatelské úlohy jsou typické dvě krajnosti: informační strohost a informační hutnost.

\footnotetext{
${ }^{12}$ „Když jsem po univerzitních studiích začal vyučovat matematiku na střední škole, byl jsem přesvědčen, že náležitým vysvětlením definic, vět a důkazů dovedu studenty k porozumění matematice. V praxi jsem poznal, že důležitější pro pochopení problematiky jsou př́iklady." (Kuřina, 2005: s. 19)

${ }^{13}$ V̌̌echny níže uvedené úlohy mají aspoň jednu takovou část.
} 


\section{1 ÚlLOHY INFORMAČNĚ STROHÉ}

Badatelské úlohy s velmi malým množstvím vstupních informací (podmínek) budeme nazývat úlohy informačně strohé. Badatelské úlohy tohoto typu jsou na vstupu hodně neurčité a díky tomu nabízejí mnoho způsobů, jak neurčitost transformovat v určitost - mají velký badatelský potenciál.

Uved'me si př́klady několika takových úloh.

* Uloha 1: Kde je v tvém okolí číslo 7?

Úloha vytváří otevřenou situaci, ve které žáci shromaždují různé modely související s číslem 7 (příp. s jiným číslem). Je možné ji začlenit do výuky již v 1 . třídě, v období probírání numerace do 10.

* Úloha 2: Obsah neznámého obrazce je $64 \mathrm{~cm}^{2}$. Jak by tento obrazec mohl vypadat?

Tato úloha směřuje k prekonceptům pojmu obsah. Podrobně o podobné úloze směřující k prekonceptům pojmu objem se zmiňujeme (Samková, 2014).

* Ulloha 3: Obsah čtverce je $64 \mathrm{~cm}^{2}$. Jak by tento čtverec mohl vypadat?

Tato informačně strohá úloha na první pohled nevypadá jako badatelská, ale když se nad ní hlouběji zamyslíme, tak zjistíme, že i při jejím řešení se dají uplatnit badatelské postupy.

Mezi informačně strohé badatelské úlohy patří často úlohy rozvíjející finanční gramotnost či úlohy z propedeutiky statistiky.

* Uloha 4: Zjistěte $v$ obchodech $v$ okolí svého bydliště ceny jablečného džusu a rozhodněte, ve kterém obchodu se vyplatí ďzus koupit.

Úloha se zpracovává formou projektu; žák sám rozhoduje, ve kterých obchodech si bude zjištovat potřebné údaje.

Tato úloha je zároveň příkladem problému, jehož řešení mohou být nejasně klasifikovatelná, nebot výběr nejlepšího řešení ovlivňují individuální názory žáků na zkoumanou situaci: Chci koupit velké nebo malé balení džusu? Chci koupit větši balení, pokud vyjde v přepočtu levněji? Vejde se mi velké balení do lednice? Mám na něj dost peněz? Stihneme ho včas vypit? Chci strávit více času cestou na nákup do vzdáleného obchodu? Chci nést těžký nákup ze vzdáleného obchodu? Nebo raději nakoupím o trochu dráž v obchodě vedle našeho domu? Chci využit akce a koupit více baleni najednou, protože to vyjde levněji? Jsem ochotný si na takovou akci počkat do př́štího týdne?...

Problematika ovlivňování volby nejlepšího řešení individuálními názory žáků je rozpracována např. v sadě článků M. Komana a M. Tiché česky publikovaných v časopisu Matematika - fyzika - informatika: (Koman \& Tichá, 1995, 1996a, 1996b, 1997).

Náměty na další badatelské úlohy rozvíjející finanční gramotnost naleznete v (Samková, 2012b) a (Petrášková, 2013).

* Úloha 5: Jak vypadá typický žák v naši tř́dě?

Úloha směřuje k prekonceptům statistického pojmu modus, je inspirována studií Fieldingové-Wellsové a Makarové (2008). Podobnou úlohu využila Kubínová (2002) ve svém projektu „Pepík Náš aneb Jaká je ta naše tř́ida“ k expozici aritmetického průměru a různých druhů závislostí. 


\section{2 ÚLOHY INFORMAČNĚ HUTNÉ}

Opakem informačně strohých úloh jsou úlohy informačně hutné, jejich vstupní situace je daná velkým množstvím informací, ve kterém se žák musí správně zorientovat. Součástí vstupních informací může být i popis nějakého složitěji definovaného prostředí (ve vztahu k aktuálním znalostem žáků).

* Úloha 6: Jaký obvod má mnohoúhelník, který je sestaven ze čtyř shodných pravoúhlých trojúhelniki s délkami stran 3, 4, 5?

Přestože je informačně hutná, umožňuje tato úloha volit různé cesty a různý rozsah oblasti bádání. Podrobněji v (Roubíček, 2014b).

Trojúhelníková mozaika použitá v úloze 6 je prř́klad geometrického prostředí, ve kterém lze uplatnit badatelský přístup. Takových prostředí existuje celá řada; některá z nich jsou běžně využívána ve školní praxi, například úlohy řešené ve čtvercové síti (na geoboardu) nebo pomocí různých stavebnic (Polydron, Geomag, Soma kostka); jiná jsou využívána méně, například úlohy řešené pomocí zrcátek, stř́iháním nebo překládáním papíru.

* Úloha 7: Rozstřihni čtverec ABCD podle úsečky EB na dvě části (bod E je středem strany DC). Skládej různé tvary tak, že díly spojiš celou stranou. Kolik tvaru vznikne?

Více podrobností a další podobné úlohy jsou v (Hošpesová \& Samková, 2012).

Mezi méně obvyklá prostředí patří také pravidelná trojúhelníková sít.

* Úloha 8: Sestav rüzné obrazce tvořené shodnými rovnostrannými trojúhelníky ze třech párátek. Kolik párátek je potřeba k sestaveni nějakého většího obrazce?

Tato úloha vychází z geometrického prostředí, ve kterém řešitel uvažuje různé geometrické obrazce, ale jejím výstupem je aritmetické či algebraické vyjádření změny velikosti obrazce. Zadání úlohy nevymezuje způsob, jakým mají být obrazce zvětšovány, a tak umožňuje mnoho různých bádání. Podrobněji v (Roubíček, 2014b).

Vstupní informace badatelské geometrické úlohy může být také vizualizovaná reprezentovaná obrázkem či fotografií.

* Úloha 9: Prohlédni si dlažbu chodníku na obr. 4. Jak lze vytvořit takovou mozaiku?

Obr. 4: Dláždění

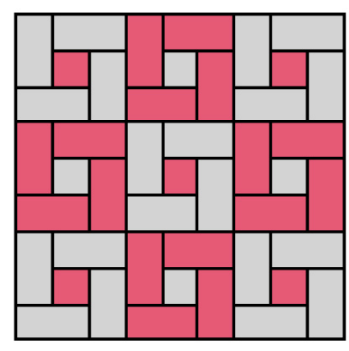

Podle stručného textu zadání by mohla být úloha mylně klasifikována jako informačně strohá, ale je nutné si uvědomit, že obrázek, který je součástí zadání úlohy, obsahuje velké množství důležitých informací. Podrobně vyřešené podobné úlohy naleznete v (Roubíček, 2014a, 2014b). 
Obr. 5: Č́selná zed’

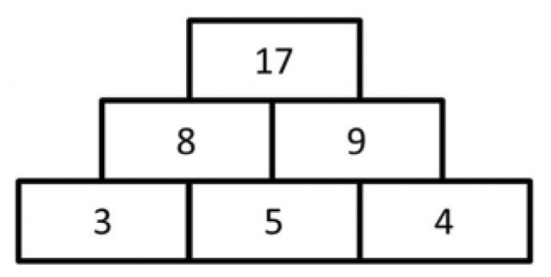

Tato úloha je inspirována publikací (Wittmann \& Müller, 1990). Podobně jako v úloze 9 je text úlohy krátký, ale informace jsou skryty v obrázku.

Informačně hutnými badatelskými úlohami bývají i ty úlohy z propedeutiky statistiky, které v zadání obsahují datové soubory.

* Úloha 11: Na farmě maji jedno políčko s fazolemi na sluníčku a druhé ve stínu. $V$ tab. 2 jsou uvedeny přibližné hmotnosti fazolí na těchto políčcích 6, 8 a 10 týdnů od vysázení. Které poličko je vhodnějši pro pěstováni fazolí?

Tab. 2: Hmotnosti fazolí

\begin{tabular}{|l|l|l|l|l|l|l|l|}
\hline SLUNCE & 6 týdnů & 8 týdnů & 10 týdnů & STí́N & 6 týdnů & 8 týdnů & 10 týdnů \\
\hline Řádek 1 & $9 \mathrm{~kg}$ & $12 \mathrm{~kg}$ & $13 \mathrm{~kg}$ & Řádek 1 & $5 \mathrm{~kg}$ & $9 \mathrm{~kg}$ & $15 \mathrm{~kg}$ \\
\hline Řádek 2 & $8 \mathrm{~kg}$ & $11 \mathrm{~kg}$ & $14 \mathrm{~kg}$ & Řádek 2 & $5 \mathrm{~kg}$ & $8 \mathrm{~kg}$ & $14 \mathrm{~kg}$ \\
\hline Řádek 3 & $9 \mathrm{~kg}$ & $14 \mathrm{~kg}$ & $18 \mathrm{~kg}$ & Řádek 3 & $6 \mathrm{~kg}$ & $9 \mathrm{~kg}$ & $12 \mathrm{~kg}$ \\
\hline
\end{tabular}

Úloha je převzata z (English \& Watters, 2004), článek popisuje zkušenosti se zařazením podobných úloh do výuky ve 3 . ročníku ZŠS.

Pouhou změnou otázky na Kolik fazolí bude na políčcích 12 týdnů od vysázení? vytvoříme úlohu zaměřenou na matematické modelování.

Jednoduché badatelské úlohy můžeme různě skládat a získat úlohy složené.

\section{3 ÚLOHY HIERARCHICKY SLOŽENÉ}

Velký badatelský potenciál mají úlohy hierarchicky složené. Při tomto způsobu skládání se výstupní situace jedné úlohy stává součástí vstupní situace úlohy další (viz obr. 6). Samo toto složení má v sobě prvky neurčitosti, protože řešitel nikdy dopředu neví, které součásti řešení první úlohy budou pro druhou úlohu relevantní a které nikoliv.

Obr. 6: Dvě badatelské úlohy složené hierarchicky, inspirováno hierarchickým schématem slovní úlohy o dvou operacích (Nesher \& Hershkovitz, 1994)

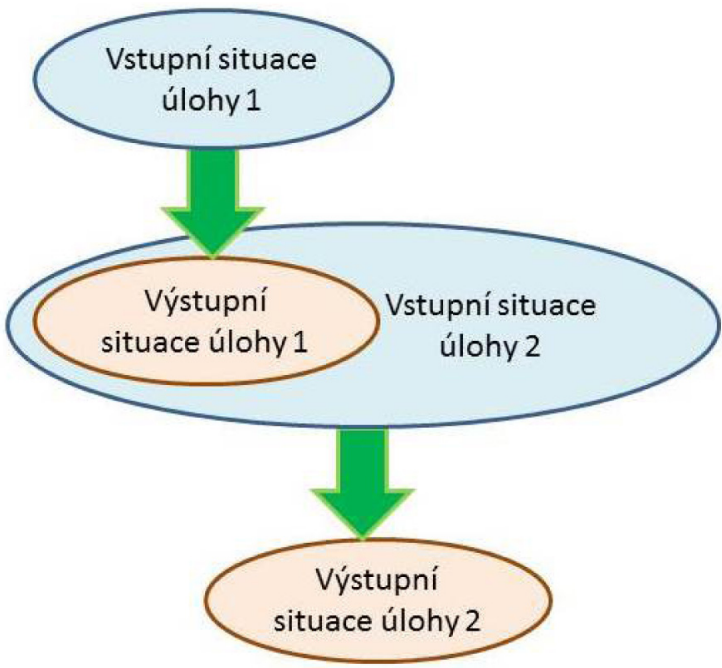


* Úloha 12:

a) Rozstřihni čtverec jedním rovným střihem na dva díly. Z těchto dílů skládej tvary. Kolik tvaru vznikne?

b) Pokus se čtverec rozstřihnout tak, aby mohlo vzniknout co nejvíce tvarů. Jaký je nejvyšš počet tvarü?

Tato úloha volně navazuje na úlohu 7 . Část a) může být samostatnou badatelskou úlohou, při řešení části b) využíváme poznatky získané při řešení úlohy a). Podrobněji v (Hošpesová \& Samková, 2012).

* Úloha 13: Prohlédni si čŕselnou zed’ na obr. 5.

a) Jak lze vytvořit takovou zed? Najdi všechny číselné zdi, které můžeš postavit se základními kameny 3, 4, 5 (podobně jako na obr. 5). Zdi vypočti a porovnej.

b) Sám si vyber tři základni kameny a počítej stejně.

c) Popiš, čeho sis všiml.

d) Müžeš to odưvodnit?

Tato úloha, která je převzata z publikace (Wittmann \& Müller, 1990), je rozšířením úlohy 10. Část a) může být samostatnou badatelskou úlohou, při řešení částí b)-d) využíváme poznatky získané při řešení předchozích částí (např. pravidlo, podle kterého se čísla do zdi doplňují).

\section{* Úloha 14:}

a) Najděte a popište pravidlo, podle kterého se doplňuji čísla v trojúhelníku na obr. 7.

b) Rozhodněte, které z následujících tvrzeni je pravdivé, a své tvrzení zdůvodněte:

- Součet vnějších čísel se rovná součtu vnitřnich čísel.

- Součet všech tři vnějších čísel müže být číslo sudé i liché.

c) Doplňte vnitřni čisla, jsou-li vnějšimi čisly (i) 6, 13 a 14; (ii) 13, 21 a 23.

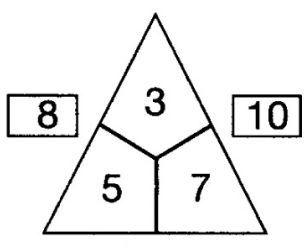

Obr. 7: Číselný trojúhelník

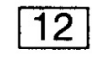

Tato úloha je inspirována výukovým prostředím popsaným např. v publikaci Krauthausena a Schererové (2013). Cást a) by mohla být samostatnou badatelskou úlohou. Její výstupní informace (tj. znění pravidla pro doplňování čísel) je nezbytnou součástí vstupních informací částí b) a c).

* Úloha 15: Vytvořte jednoduchou úlohu, příběh, historku ke schématu na obr. 8 vlevo. Jeden z údajů na obr. 8 vlevo nahradte jednoduchou úlohou (např. tak, jak je to znázorněno na obr. 8 vpravo), aby vznikla úloha, $k$ jejímuž vyřešení jsou potřeba dva výpočty. Jak jinak je možné rozvíjet řetězec? Jaké různé slovní úlohy $k$ nim můžeme vytvorit? 
Obr. 8: Struktura slovní úlohy
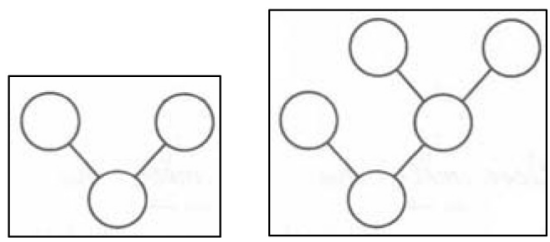

Idea přiřazování schémat slovním úlohám se objevuje již v učebnicích pro 2. ročník (Kittler \& Kuřina, 1994).

My jsme tuto úlohu využili také v kurzech pro budoucí učitele 1. i 2. stupně ZŠ. Ukázalo se, že upravování struktury slovní úlohy pomáhá studentům vytvořit si nadhled, který jim umožňuje lépe chápat řešení úlohy (podrobněji v Tichá, 2014; Tichá \& Hošpesová, 2014).

*/**/*** Úloha 16:

a) Rozlož číslo 10 na součet dvou (přirozených) čísel a tato dvě čísla vynásob. Jaký nejmenši a jaký největši součin dostaneš?

b) Č́slo 10 rozlož na součet tři (přirozených) čísel a tato tři čísla vynásob. Jaký nejmenši a jaký největši součin dostaneš?

c) Číslo 10 rozlož na součet libovolného počtu (přirozených) čísel a tato čisla vynásob. Jaký nejmenši a jaký největši součin dostaneš?

d) Jak bude řešení úloh a) až c) vypadat pro čisla 7, 8, 9 a 11?

e) Existuje strategie pro řě̌ení úloh a) až c) nezávislá na volbě rozkládaného čísla?

f) Jak se situace změní, budeme-li úlohu řešit v oboru racionálních či reálných čisel?

I v tomto př́ípadě by úlohy a), b) a c) mohly být samostatnými badatelskými úlohami. Při řešení úloh b) až f) využiváme poznatky získané při řešení úloh, které jim předcházely (více podrobností v Artigue \& Baptist, 2012: s. 7). Velice zajímavé je zdůvodnění strategií pro e) a f) a jejich vztah.

Poznámka k obtížnosti: * je určena pro úlohy a)-e), ** pro f) v oboru racionálních čísel, *** pro f) v oboru reálných čísel.

\section{4 ÚlOHY S DYNAMICKÝM VSTUPEM}

Složíme-li k sobě více úloh se stejnou otázkou, dostaneme úlohu s dynamickým ${ }^{14}$ vstupem. Každá další dílčí úloha přidává vstupní informace (podmínky), ale otázku nemění, a tak se nemění ani výstupní situace (viz obr. 9). Složená úloha má méně řešení než dílčí úlohy, protože její řešení musí vyhovovat všem dílčím podmínkám. Úlohu s dynamickým vstupem bychom také mohli charakterizovat jako úlohu postupně informačně upřesňovanou.

Obr. 9: Složení dvou úloh se stejnou otázkou

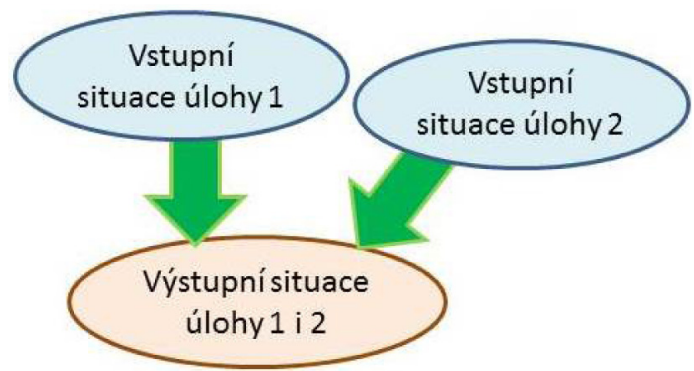

\footnotetext{
${ }^{14}$ Dynamický ve smyslu projevující vývoj.
} 


\section{* Úloha 1\%:}

a) Ve třídě je 18 členů pěveckého a 16 členů sportovního kroužku. Co můžeš s jistotou ř́ci o počtu dětí ve třídě?

b) Doplněk k úloze a): 6 dětí je členy obou kroužkư.

c) Dalši doplněk: 4 děti nejsou členy ani pěveckého ani sportovního kroužku.

Tato úloha je převzata z učebnice (Kittler, Kuřina \& Tichá, 1994: s. 80).

Úloha b) vznikla složením úlohy a) a úlohy Ve tř́dě je 6 dětí členy sportovního i pěveckého kroužku. Co müžeš s jistotou ř́ci o počtu dětí ve tř́dě?; úloha c) vznikla složením úlohy b) a úlohy 4 děti ve třidě nejsou členy ani pěveckého ani sportovního kroužku. Co můžeš s jistotou ř́ici o počtu dětí ve tř́́dě?

Chceme-li plně využít badatelský potenciál této úlohy, můžeme řešit každou její dílčí úlohu zvlášt a sledovat, jak řešení dílčích úloh souvisí s řešeními úloh z nich složených.

\section{*/** Úloha 18:}

a) Maji následujicí trojice čísel nějakou společnou vlastnost?

$[15,70,95],[55,60,65],[60,50,70],[45,45,90],[100,20,60]$, $[43,72,65],[20,45,115],[155,20,5], \ldots$

b) Čísla v trojicích udávají velikosti úhlů v trojúhelníku. Ověřte, že vámi nalezená společná vlastnost plati pro úhly v každém trojúhelníku.

Úloha a) vznikla složením úloh Jaký je vztah mezi čísly v trojici $[15,70,95]$ ?, Jaký je vztah mezi čísly v trojici $[55,60,65]$ ? V tomto případě by řešení dílčích úloh bylo př́liš časově náročné, vhodnější je se rovnou soustředit na řešení složené úlohy.

Žákům můžeme dát $\mathrm{k}$ dispozici dlouhý seznam trojic, nebo je možné využít nějaký dynamický geometrický software (GeoGebra, Cabri aj.) a nechat si trojice úhlů generovat jeho prostřednictvím. Žák se může stát i aktivním spolutvưrcem úlohy, když trojúhelníky v počítači bude sám vybírat, a tím ovlivňovat, které trojice čísel se stanou součástí zadání (podrobněji v Samková, 2014).

Poznámka k obtížnosti: * pro úlohu a), ** pro úlohu b).

\section{5 ÚlOHY S DYNAMICKÝM VÝSTUPEM}

Složíme-li k sobě více úloh se stejnou vstupní situací, dostaneme úlohu s dynamickým výstupem. Každá další dílčí úloha přidává novou výstupní situaci (otázku), ale vstupní situace se nemění (viz obr. 10). Úlohu s dynamickým výstupem bychom také mohli charakterizovat jako úlohu postupně informačně vytěžovanou.

Obr. 10: Složení dvou úloh se stejnou vstupní situací

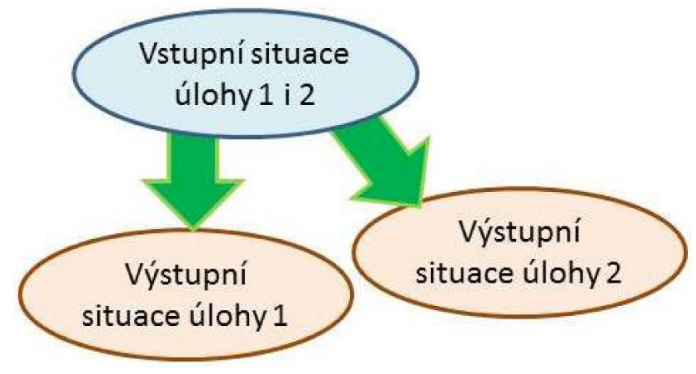


*/**/*** Úloha 19: Z 12 párátek můžeme vytvořit čtverec, jehož obsah je $9 j^{2}$.

- Dokážete z 12 párátek vytvořit n-úhelníky s obsahem 8, 7, 6, 5, 4, 3, 2, $1 j^{2}$ ?

- $S$ obsahem větším než $9 j^{2}$ ?

- S neceločíselným obsahem?

- S obsahem menšim než 1 ?

- S libovolně velkým obsahem?

- Dokážete vytvořit n-úhelniky s $n \neq 4$, jejichž obsah je 8, 7, 6, 5, 4, 3, 2, $1 j^{2}$ ?

Použít musite vždy všechna párátka.

Úloha je inspirována Pehkonenovou úlohou (1992: s. 4). Velice zajímavé je obecné řešení umožňující vytvořit $n$-úhelník s libovolným obsahem menším než $9 \mathrm{j}^{2}$ a také řešení pro $n \neq 4$ využívající Pythagorovu větu k vytvoření $n$-úhelníků s obsahem 6 , 5,4 a $3 \mathrm{j}^{2}$.

Jako přípravnou můžeme zvolit úlohu hledající všechny trojúhelníky (obdélníky, pravidelné $n$-úhelníky), které je možné z 12 párátek sestrojit.

Poznámka k obtížnosti úlohy: * pro řešení, která mohou využít čtvercovou sít; ** pro ostatní řešení; *** pro úkol nalézt všechna možná řešení, hlavně řešení pro obsah menší než $3 \mathrm{j}^{2}$ při požadavku $n \neq 4$; * pro př́pravnou úlohu.

Vhodnou kombinací několika úloh s dynamickým výstupem můžeme vytvořit úlohu, která má dynamický vstup i výstup.

* Úloha 20: Jak velké je číslo 10000 ?

Kolik je 10000 želatinových medvídků?

- Kolik je to balícků?

- Kolik vážr?

- Jak dlouho je budeme jist, když budeme mit každý den jednoho medvídka?

Kolik je 10000 špaget?

- Kolik je to balení?

- Jak dlouhý proužek by vytvořily, kdybychom je dali za sebou?

- Kolik $100 \mathrm{~g}$ porcí bychom z nich uvařili?

Kolik je 10000 listio papíru?

- Kolik je to balíků?

- Jak vysoký komín bychom z nich postavili?

- Jakou plochu bychom s nimi mohli vyplnit?

Kolik je 10000 minut?

- Kolik je to dní?

- Kolik je to dni školního vyučování?

- Kolik je to prospaných nocí?

Za jak dlouho vyjmenuješ všechna čísla od 1 do 10000 ?

Ceské pracovní listy k dalším badatelským úlohám jsou také na webu (FP, 2013). 


\section{ZÁVĚR}

Teoretické rámce, které korespondují s BOVM (viz oddíl 4), mají za sebou v evropském i českém kontextu více či méně dlouhou historii a jí odpovídající objem provedených šetření. BOVM jako takové však v Evropě dlouhou tradici nemá, a tak mezi publikacemi souvisejícími s BOVM můžeme nalézt hlavně aplikační výstupy z projektů.

Badatelsky orientovanému vyučování přírodovědným předmětům se v poslední době věnovaly dvě rozsáhlé studie (Hattie, 2009; Minner, Levy \& Century, 2010). První z nich analyzuje 205 dílčích výzkumů a na jejich základě ukazuje, že z hlediska znalostí žáků má BOV (i) největší efekt na prvním stupni ZŠ a tento efekt s postupujícím věkem žáků klesá; (ii) dvakrát větší vliv na procesy než na obsah. Druhá studie na základě výzkumné otázky Jaký je vliv badatelsky orientované výuky př́rodovědných předmětů na výsledky žáků základních škol? analyzuje výsledky 138 dílčích výzkumů a na jejich základě konstatuje, že efekt BOV není tak výrazně pozitivní, jak očekávali, ale že u žáků indikují zlepšení v konceptuálním porozumění př́rodovědným předmětům jako důsledek aktivní participace v badatelském procesu.

Za pozornost rozhodně stojí publikace (Bruder \& Prescott, 2013), která uvádí rozsáhlý přehled výzkumu souvisejícího s BOV, včetně výzkumů zaměřených na korespondující teoretické rámce. ${ }^{15}$ Výzkumy zaměřené přímo na BOV jsou zde výhradně z oblasti vyučování př́rodovědným předmětům. Tato přehledová studie se také věnuje výzkumo̊m, které na BOV pohlížejí kriticky. Autorky na jejich základě upozorňují (s. 818), že občas jsou očekávání směřovaná směrem k BOV př́liš vysoká, zvláště v případech, kdy učitel považuje BOV za svoji nejoblíbenější metodu. Jako řešení navrhují doplňovat BOV vhodnou kombinací dalších výukových metod.

V oblasti BOV a BOVM je mnoho neprobádaného, pro další výzkum v didaktice matematiky se tak nabízí mnoho důležitých otázek: Které strategie jsou relevantní pro BOV a jak se je mohou žáci efektivně naučit využívat? Jak se mohou žáci efektivně naučit klást správně (matematické) otázky, správně prezentovat své závěry? Jak žáky při BOV hodnotit? Jakým způsobem ovlivňují úspěšnost BOV okolní podmínky (např. podpora učitele)? (Bruder \& Prescott, 2013: s. 820).

Dle našeho názoru je důležitým předstupněm implementace BOV do matematického vzdělávání odpovídající reforma vzdělávání učitelů. Jako jednu z možných cest vidíme zavedení badatelsky orientovaných matematických kurzů do vysokoškolské přípravy budoucích učitelů, ve kterých by si tito budoucí učitelé mohli prožít BOVM z pozice žáka. V rámci projektu Zkvalitňování znalostí matematického obsahu u budoucích učitelů 1. stupně prostřednictvím badatelsky orientované výuky, podporovaném GA ČR, realizujeme badatelsky orientované kurzy aritmetiky a didaktiky matematiky pro studenty učitelství pro 1. stupeň Z ̌ a sledujeme vliv tohoto typu vyučování na jejich znalosti matematického obsahu. Vycházíme z předpokladu, že řešení vhodných úloh a jejich didaktická analýza ukáže studentům, jak důležitá je jejich znalost matematiky a jak je nutné (a potřebné) ji využívat při přípravě a realizaci výuky matematiky. Naše dosavadní zkušenosti ukazují, že studenti považují BOVM za užitečné a jsou motivováni zúčastnit se činností, které jsou na něm založeny. Selhávají ale v propojování toho, co se naučili v teoretických kurzech, s požadavky, které na ně klade didaktická analýza úloh a realizace BOVM

\footnotetext{
${ }^{15} \mathrm{Z}$ pohledu našeho př́spěvku je zajímavá zde uvedená anglická studie (Boaler, 1998), která sleduje vliv otevřeného př́stupu $\mathrm{k}$ vyučování matematice na zkušenosti a porozumění žáků ve věku 13-16 let.
} 
v praxi. Cestou k uplatňování BOVM je, podle našeho soudu, (a) záměrné postupné budování propojení mezi učebními obsahy základního vzdělávání a matematikou i v nedidaktických matematických kurzech pro budoucí učitele; (b) prokazování užitečnosti matematiky (pomocí vhodných témat). Využívání BOVM v kurzech matematiky i její didaktiky vytváří porozumění roli uvažování ve vzdělávání (nejen matematickém) a souvisejících generalizací, hledaní shod a rozdílností, objevování pravidelností, vzorů, dovednosti vizualizovat, najít vhodnou reprezentaci a objasnit ji. Také se podpoří povědomí studentů o vhodné argumentaci a různých možnostech, jak dospět k závěrům.

\section{PODĚKOVÁNí}

Tato studie byla realizována s podporou projektu GAČR 14-01417S Zkvalitňování znalostí matematického obsahu u budoucích učitelì 1. stupně prostřednictvím badatelsky orientované výuky a RVO 67985840.

\section{LITERATURA}

Arnold, V. I. (2000). Polymathematics: Is mathematics a single science or a set of arts? In V. Arnold, M. Atiyah, P. Lax \& B. Mazur (Eds.), Mathematics: Frontiers and perspectives (403-416). Providence: AMS.

Artigue, M. \& Baptist, P. (2012). Inquiry in Mathematics Education (Resources for Implementing Inquiry in Science and in Mathematics at School). Dostupné z http://www.fibonacci-project.eu/

Artigue, M. \& Blomhøj, M. (2013). Conceptualizing inquiry-based education in mathematics. ZDM Mathematics Education, 45, 797-810.

Artigue, M., Baptist, P., Dillon, J., Harlen, W. \& Léna, P. (2011). Learning through inquiry. The Fibonacci Project Resources. Dostupné z http://fibonacci-project.eu

Blomhøj, M. \& Jensen, T. H. (2003). Developing mathematical modelling competence: conceptual clarification and educational planning. Teaching Mathematics and its Applications, 22(3), 123-139.

Boaler, J. (1998). Open and closed mathematics: Student experiences and understandings. Journal for Research in Mathematics Education, 29(1), 41-62.

Brousseau, G. (1997). Theory of Didactical situations in mathematics. Translation from French: M. Cooper, N. Balacheff, R. Sutherland \& V. Warfield. Kluwer Academic Publishers.

Brousseau, G. (2012). Úvod do teorie didaktických situací v matematice. Z francouzštiny přeložili J. Novotná, J. Bureš \& L. Růžičková. Praha: Karolinum.

Bruder, R. \& Prescott, A. (2013). Research evidence on the benefits of IBL. ZDM Mathematics Education, 45, 811-822.

Bureš, J. (2014). Žákovská tvorba slovních úloh jako indikátor matematické kultury žáků $Z \breve{S}$. Praha: Univerzita Karlova, Pedagogická fakulta (dizertační práce).

Cai, J. (2010). Commentary on problem solving heuristics, affect, and discrete mathematics: A representational discussion. In B. Sriraman \& L. English (Eds.), Theories of mathematics education (251-258). New York: Springer. 
Dewey, J. (1938). Logic: The theory of inquiry. New York: Holt.

Doerr, H. M. \& English, L. D. (2003). A modeling perspective on students' mathematical reasoning about data. Journal for Research in Mathematics Education, 34(2), 110-136.

Dorier, J.-L. \& Maaß, K. (2014). Inquiry-based mathematics education. In S. Lerman (Ed.), Encyclopedia of Mathematics Education (300-304). Dordrecht: Springer.

Eastwell, P. (2009). Inquiry learning: Elements of confusion and frustration. The American biology teacher, 71(5), 263-264.

English, L. \& Watters, J. (2004). Mathematical modeling in the early school years. Mathematics Education Research Journal, 16(3), 59-80.

Fibonacci Project (2013). Ukázky pracovních listů vytvořených a vyzkoušených během projektu. Dostupné z http://www.pf.jcu.cz/stru/katedry/m/envilisty.html

Fielding-Wells, J. \& Makar, K. (2008). Using mathematical inquiry to engage student learning within the overall curriculum. In J. Adler \& D. Ball (Eds.), Eleventh International Congress of Mathematics Education (ICME11) mathematical knowledge for teaching (1-17). Monterrey, Mexico.

Fishbein, E. (1999). Intuition and schemata in mathematical reasoning. Educational Studies in Mathematics, 38, 11-50.

Fradd, S. H., Lee, O., Sutman, F. X. \& Saxton, M. K. (2001). Promoting science literacy with English language learners through instructional materials development: A case study. Bilingual Research Journal, 25(4), 417-439.

Freudenthal, H. (1973). Mathematics as an educational task. Dordrecht: Reidel Publishing Company.

Freudenthal, H. (1991). Revisiting mathematics education. China lectures. Dordrecht: Kluwer.

Hattie, J. (2009). Visible learning. A synthesis of over 800 metaanalyses relating to achievement. London: Routledge.

Hejný, M. (2004). Chyba jako prvek edukační strategie učitele. In M. Hejný, J. Novotná \& N. Stehlíková (Eds.), Dvacet pět kapitol z didaktiky matematiky, sv. 1 (63-80). Praha: Univerzita Karlova v Praze, Pedagogická fakulta.

Hejný, M. (2007). Budování matematických schémat. In A. Hošpesová, N. Stehlíková \& M. Tichá (Eds.), Cesty zdokonalování kultury vyučování matematice (81-122). České Budějovice: Jihočeská univerzita.

Hejný, M. (2014). Vyučování matematice orientované na budování schémat: aritmetika 1. stupně. Praha: Univerzita Karlova v Praze, Pedagogická fakulta.

Hejný, M. \& Kuřina, F. (2009). Ditě, škola a matematika: Konstruktivistické př́rstupy k vyučování. Praha: Portál.

Hošpesová, A. \& Samková, L. (2012). Skládání tvarů jako podnět k badatelským aktivitám v geometrii na ZS̆. In Sborník konference Jak učit matematice žáky ve věku 10-16 let (123-130). Plzeň: Vydavatelský servis.

Hošpesová, A., Jagoda, E., Kouřilová, J., Macháčková, J., Mazehóová, Y., Roubíček, F., Stuchlíková, I., Swoboda, E. \& Tichá, M. (2010). Náměty pro přirozenou diferenciaci $v$ matematice na 1. stupni základního vzdělávání. Podnětná prostředí v geometrii. Rzeszów (Polsko): Wydawnictwo Uniwersytetu Rzeszowskiego. 
Janoušková, S., Novák, J. \& Maršák, J. (2008). Trendy ve výuce př́rodovědných oborů $\mathrm{z}$ evropského pohledu. Acta Facultatis Paedagiogicae Universitatis Trnaviensis, Ser. D, Supplementum 2(12), 129-132.

Kaiser, G. \& Sriraman, B. (2006). A global survey of international perspectives on modelling in mathematics education. ZDM Mathematics Education, 38(3), 302-310.

Kaiser, G., Blum, W., Borromeo Ferri, R. \& Stillman, G. (Eds.). (2011). Trends in teaching and learning of mathematical modelling. Dordrecht: Springer.

Kittler, J. \& Kuřina, F. (1994). Matematika pro 2. ročník. Praha: MÚ AV ČR a ALBRA.

Kittler, J., Kuřina, F. \& Tichá, M. (1994). Matematika pro 3. ročník. Praha: MÚ AV ČR a ALBRA.

Koman, M. \& Tichá, M. (1995). Řešíme úlohy o nákupech, cenách, zisku. Matematika fyzika - informatika, 5(3), 113-117 a 5(4), 172-177.

Koman, M. \& Tichá, M. (1996a). Cestování - čas - peníze. Matematika - fyzika informatika, 5(5), 227-232 a 5(6), 281-284.

Koman, M. \& Tichá, M. (1996b). Jedeme na výlet - vlakem, autobusem, možná i jinak. Matematika - fyzika - informatika, 5(8), 399-406 a 5(9), 449-454.

Koman, M. \& Tichá, M. (1997). Jak v matematice zvládají žáci zkoumání situací z praxe (Cestování - čas - peníze). Matematika - fyzika - informatika, 7(1), 2-12.

Komenský, J. A. (1948). Didaktika velká. Brno: Komenium.

Krauthausen, G. \& Scherer, P. (2013). Manifoldness of tasks within a substantial learning environment: Designing arithmetical activities for all. In J. Novotná \& H. Moraová (Eds.), Proceedings of the International Symposium Elementary Maths Teaching: Tasks and tools in elementary mathematics (171-179). Praha: Univerzita Karlova v Praze, Pedagogická fakulta.

Kubínová, M. (2002). Projekty ve vyučování matematice - cesta $k$ tvořivosti a samostatnosti. Praha: Univerzita Karlova v Praze, Pedagogická fakulta.

Kuřina, F. (1976). Problémové vyučování v geometrii. Praha: SPN.

Kư̌ina, F. (1978). Vyučování matematice a modely. Matematika a fyzika ve škole, 8, 641-650.

Kư̌ina, F. (2002). O matematice a jejím vyučování. Obzory matematiky, fyziky a informatiky, 31(1), 1-8.

Kuřina, F. (2005). Geometrie a geometrické vzdělávání. In S. Olivík (Ed.), Sborník př́spěvků 25. Konference o geometrii a počítačové grafice (15-22). Praha: JČMF.

Kuřina, F. (2011). Matematika a řešeni úloh. České Budějovice: Jihočeská univerzita, Pedagogická fakulta.

Lederman, N. G. \& Abd-El-Khalick, F. (1998). Avoiding de-natured science: Activities that promote understanding of the nature of science. In W. McComas (Ed.), The nature of science in science education: Rationales and strategies (83-126). Boston: Kluwer.

Lederman, N. G., Abd-El-Khalick, F., Bell, R. L. \& Schwartz, R. E. (2002). Views of nature of science questionnaire: Toward valid and meaningful assessment of learners' conceptions of nature of science. Journal of Research in Science Teaching, 39(6), $497-521$.

Mareš, J. \& Gavora, P. (1999). Anglicko-český pedagogický slovník. Praha: Portál. 
McComas, W. F. (Ed.). (1998). The nature of science in science education: Rationales and strategies. Boston: Kluwer.

Minner, D., Levy, A. \& Century, J. (2010). Inquiry-based science instruction - what is it and does it matter? Results from a research synthesis years 1984 to 2002. Journal of Research in Science Teaching, 47(4), 474-496.

National Research Council (1996). National science education standards. Washington, DC: National Academy Press.

National Research Council (2000). Inquiry and the national science education standards. Washington, DC: National Academy Press.

Nesher, P. \& Hershkovitz, S. (1994). The role of schemes in two-step problems: analysis and research findings. Educational Studies in Mathematics, 26, 1-23.

Nohda, N. (2000). Teaching by open-approach method in Japanese mathematics classroom. In Proceedings of the Conference of the International Group for the Psychology of Mathematics Education, Hiroshima, Japan, Vol. 1 (39-53). Hiroshima, Japan: Hiroshima University.

Nováková, H. (2013). Analýza a priori jako součást přípravy učitele na výuku. Scientia in educatione, $4(2), 20-51$.

Novotná, J. \& Hošpesová, A. (2013). Students and Their Teacher in a Didactical Situation. A Case Study. In B. Kaur, G. Anthony, M. Ohtani \& D. Clarke (Eds.), Student Voice in Mathematics Classrooms around the World (133-142). Rotterdam: Sense Publishers.

Novotná, J., Pelantová, A., Hrabáková, H. \& Krátká, M. (2006). Př́prava a analýza didaktických situací. Studijní materiály k projektu Podíl učitele matematiky ZS̆ na tvorbě ŠVP. Dostupné z

http://class.pedf.cuni.cz/NewSUMA/FileDownload.aspx?FileID=94

Papáček, M. (2010). Badatelsky orientované přírodovědné vyučování - cesta pro biologické vzdělávání generací Y, Z a alfa? Scientia in educatione, 1(1), 33-49.

Patáková, E. (2013). Metody tvorby úloh pro nadané žáky. Praha: Univerzita Karlova v Praze, Pedagogická fakulta.

Pehkonen, E. (1992). Using problem fields as a method of change. The Mathematics Educator, 3(1), 3-6.

Pehkonen, E. (1995). Using open-ended problems in mathematics. ZDM Mathematics Education, 27(2), 55-57.

Petrášková, V. (2013). Pěstování finanční gramotnosti ve vzdělání žáků 2. stupně ZŠ. Matematika - fyzika - informatika, 22(3), 173-182.

Pólya, G. (1945). How to solve it. New Jersey: Princeton University Press.

Pólya, G. (1962). Mathematical discovery (Vol. 1). New York: Wiley.

Průcha, J., Walterová, E. \& Mareš, J. (2009). Pedagogický slovník. Praha: Portál.

Roubíček, F. (2014a). Geometrické konstrukce a pravidelné mozaiky. In Matematika 6. Matematické vzdělávání v primární škole - tradice a inovace (227-231). Olomouc: Univerzita Palackého.

Roubíček, F. (2014b). Sedm podob badatelsky orientovaného vyučování matematice II. In Sbornik konference Setkáni učiteli matematiky všech typů a stupňũ škol 2014 (169-174). Plzeň: Vydavatelský servis. 
Samková, L. (2011). Badatelsky orientované vyučování matematiky. In Sborník 5. konference Užití počítaču ve výuce matematiky (336-341). České Budějovice: Jihočeská univerzita.

Samková, L. (2012a). Jak velká je třetina koule? South Bohemia Mathematical Letters, 20(1), 25-29.

Samková, L. (2012b). Pracovní listy pro badatelsky orientované vyučování matematiky. In Sbornik konference Setkání učiteli̊ matematiky všech typů a stupňů škol 2012 (167-172). Plzeň: Vydavatelský servis.

Samková, L. (2013). Modelování reálných situací v matematice na SŠ - Stěhovací problém. South Bohemia Mathematical Letters, 21(1), 67-75.

Samková, L. (2014). Sedm podob badatelsky orientovaného vyučování matematice I. In Sborník konference Setkání učitelů matematiky všech typů a stupřů škol 2014 (187-192). Plzeň: Vydavatelský servis.

Schoenfeld, A. H. \& Kilpatrick, J. (2013). A US perspective on the implementation of inquiry-based learning in mathematics. ZDM Mathematics Education, 45, 901-909.

Schoenfeld, A. H. (1992). Learning to think mathematically: Problem solving, meta-cognition, and sense-making in mathematics. In D. Grouws (Ed.), Handbook for research on mathematics teaching and learning (334-370). New York: MacMillan.

Schwartz, R. S., Lederman, N. G. \& Crawford, B. A. (2004). Developing views of nature of science in an authentic context: An explicit approach to bridging the gap between nature of science and scientific inquiry. Science Teacher Education, 88(4) 610-645. DOI: $10.1002 /$ sce. 10128

Skemp, R. R. (1971). The psychology of learning mathematics. Penquin Books.

Stehlíková, N. (2004). Konstruktivistické přístupy k vyučování matematice. In M. Hejný, J. Novotná \& N. Stehlíková (Eds.), Dvacet pět kapitol z didaktiky matematiky, sv. 1 (11-21). Praha: Univerzita Karlova v Praze, Pedagogická fakulta.

Stehlíková, N. (Ed.). (2007). Náměty na podnětné vyučování v matematice. Praha: Univerzita Karlova, Pedagogická fakulta.

Stehlíková, N. \& Ulrychová, M. (2011). Žákovské konstrukce poznatků v matematice. Scientia in educatione, 2(2), 39-58.

Stuchlíková, I. (2010). O badatelsky orientovaném vyučování. In M. Papáček (Ed.) Didaktika biologie v Ceské republice 2010 a badatelsky orientované vyučování (129-135). Ceské Budějovice: Jihočeská univerzita.

Tichá, M. (2014). Objevování struktury slovních úloh ve vzdělávání učitelů. In Matematika 6. Matematické vzdělávání v primární škole - tradice a inovace (260-264). Olomouc: Univerzita Palackého.

Tichá, M. \& Hošpesová, A. (2011). Gramotnost učitele matematiky a tvoření úloh. In Hošpesová et al., Matematická gramotnost a vyučování matematice (39-56).

Č. Budějovice: Jihočeská univerzita.

Tichá, M. \& Hošpesová, A. (2014). Sedm podob badatelsky orientovaného vyučování matematice III. In Sborník konference Setkání učitelů matematiky všech typů a stupňu škol 2014 (217-223). Plzeň: Vydavatelský servis.

Tichá, M. \& Koman, M. (2000). Towards developing teachers' ability for grasping situations. In J. Kohnová (Ed.), Proceedings of the International Conference Teachers 
and their University Education at the Turn of the Millennium (300-306). Praha: Univerzita Karlova v Praze, Pedagogická fakulta.

Treffers, A. (1987). Three Dimensions. A Model of Goal and Theory Description in Mathematics Instruction - The Wiskobas Project. Dordrecht: Reidel Publishing Company.

Vyšín, J. (1976). Genetická metoda ve vyučování matematice. Matematika a fyzika ve škole, 6, 582-593.

Vyšín, J. (1962). Metodika řešeni matematických úloh. Praha: SPN.

Vyšín, J. (1979). O základním výzkumu a práci Kabinetu pro modernizaci vyučování matematice. Matematika a fyzika ve škole, 10, 104-112.

Vyšín, J. (1972). Tři kapitoly o problémovém vyučování matematice. Praha: SPN.

Wittmann, E. Ch. \& Müller, G. N. (1990). Handbuch produktiver Rechenübungen. Bd. 1: Vom Einspluseins zum Einmaleins. Stuttgart: Klett.

Wittmann, E. Ch. (2001). Developing mathematics education in a systemic process.

Educational Studies in Mathematics, 48, 1-20.

Zhouf, J. (2010). Tvorba matematických problémů pro talentované žáky. Praha:

Univerzita Karlova v Praze, Pedagogická fakulta.

LiBUŠE SAMKOVÁ, lsamkova@pf.jcu.cz

Jihočeská univerzita v Českých Budějovicích, Pedagogická fakulta

Katedra matematiky

Jeronýmova 10, 37115 České Budějovice, Česká republika

Alena HošPesová, hospes@pf.jcu.cz

Jihočeská univerzita v Českých Budějovicích, Pedagogická fakulta

Katedra pedagogiky a psychologie

Jeronýmova 10, 37115 Ceské Budějovice, Česká republika

FILIP RoubíČEK, roubicek@math.cas.cz

MARIE TichÁ, ticha@math.cas.cz

Matematický ústav AV ČR, v.v.i.

Kabinet pro didaktiku matematiky

Žitná 25, 11567 Praha 1, Česká republika 